\title{
Sediment Delivery by the Yukon River to the Yukon Flats, Yukon Delta and the Bering Sea
}

\author{
Kenneth R. Olson ${ }^{*}{ }^{(0)}$, James M. Lang ${ }^{2}$ \\ ${ }^{1}$ Department of Natural Resources, College of Agricultural, Consumer, and Environmental Sciences, University of Illinois, Urbana, \\ Illinois, USA \\ ${ }^{2}$ Department of Crop Sciences, College of Agriculture, Consumer, and Environmental Sciences, University of Illinois, Urbana, \\ Illinois, USA \\ Email: *krolson@illinois.edu
}

How to cite this paper: Olson, K.R. and Lang, J.M. (2020) Sediment Delivery by the Yukon River to the Yukon Flats, Yukon Delta and the Bering Sea. Open Journal of Soil Science, 10, 410-442.

https://doi.org/10.4236/ojss.2020.109022

Received: August 28, 2020

Accepted: September 22, 2020

Published: September 25, 2020

Copyright (c) 2020 by author(s) and Scientific Research Publishing Inc. This work is licensed under the Creative Commons Attribution International License (CC BY 4.0).

http://creativecommons.org/licenses/by/4.0/

\section{(cc) (i) Open Access}

\begin{abstract}
The physical, chemical and biological attributes of the Yukon River and tributary basins impact soil erosion, sediment transport and sediment delivery. The glacier, snow and permafrost melting, runoff, erosion, transport, deposition and storage of gravelly, sandy, silty and clayey sediments determine the habitat distribution and water quality within the river channels and floodplains. The ecological functioning, with food and nutrient delivery, migratory cues, breeding, habitats, and riparian and floodplain ecological cycles are all dependent on the transported sediment at specific times of the year. Annual temperatures have been rising since the 1840s which could contribute to higher runoff water flows and greater sedimentation. The primary objective was to document the sedimentation in the Yukon watershed with little soil erosion as a result of agriculture or urban development. The causes of the soil erosion and sedimentation were permafrost, alpine glacial melting, drilling for gas and oil, road construction, gold mining, cold war military sites, pipeline construction, forest fires and steep slopes.
\end{abstract}

\section{Keywords}

Denali, Alaska, British Columbia, Yukon Territory, Alyeska Pipeline, Alaska Highway, Gas and Oil Exploration, Trans-Alaska Pipeline

\section{Introduction}

The Yukon River (Figure 1), a largely uncultivated basin, transports about 58.8 million $\mathrm{mt}$ of suspended sediment annually to the Bering Sea. Each year, about $19.6 \mathrm{mt}$ of sediment are deposited on floodplains and braided reaches of the river such as the Yukon Flats (Figure 2). Organic carbon, contaminants and 


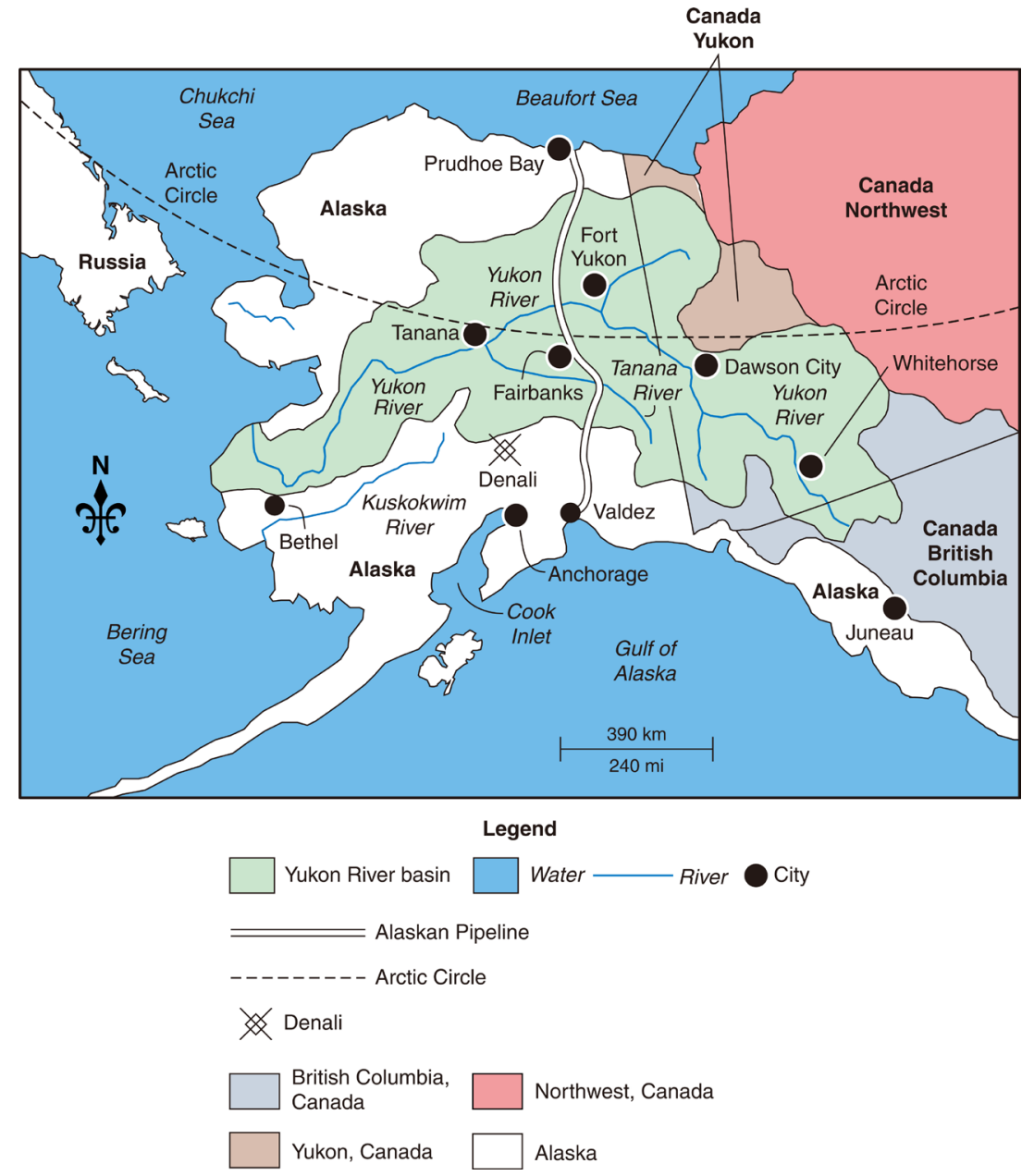

Figure 1. Alaska adjacent to the Bering Sea and the Gulf of Alaska. Map by Mic Greenberg.

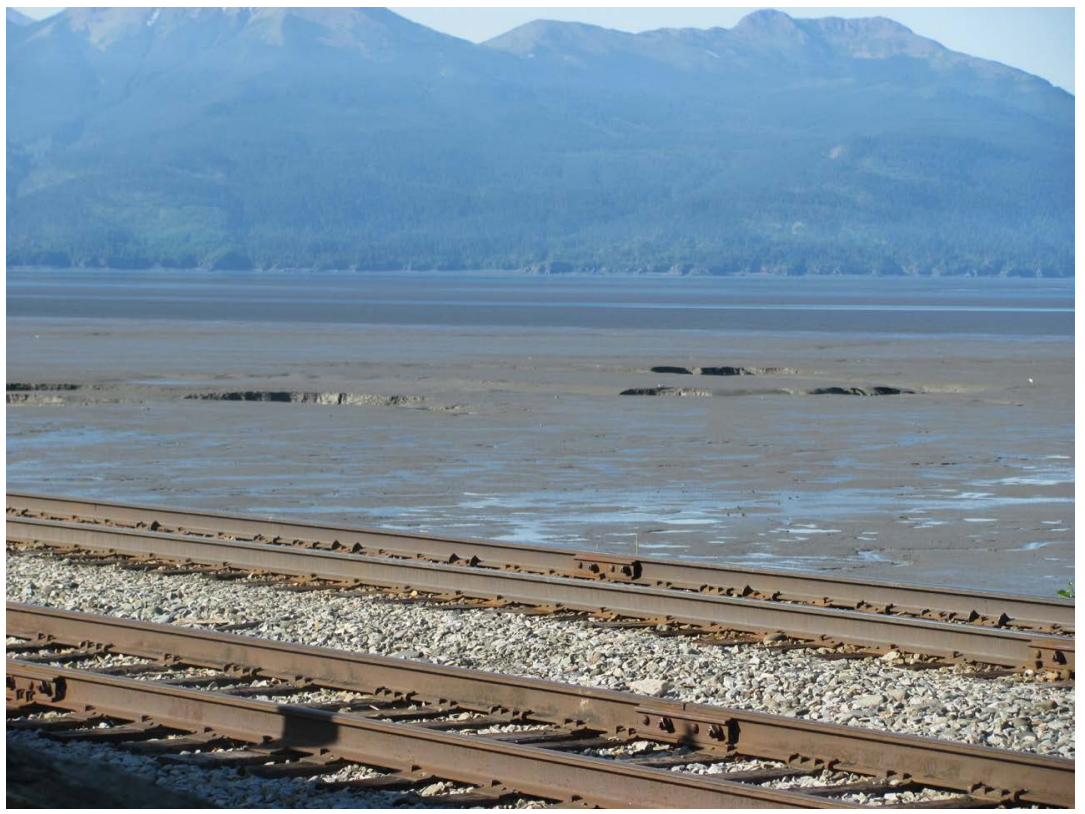

Figure 2. Mud flats in coastal areas such as Cook Inlet south of Anchorage. Railroad track in foreground. Photograph taken by Lois Wright Morton. 
nutrients are either absorbed on the sediment or in solution. The amount of the organic carbon sequestered is enormous. Total organic carbon concentrations are highest in the river regions dominated by Histosols (organic soils) (Figure 3). The human population of the Yukon River Basin is 126,000 and they live in an $854,696 \mathrm{~km}^{2}$ basin. Most of the aboriginal people (Figure 4 and Figure 5) have a subsistence lifestyle depending on edible plants and roots, berries, fish and game. The climate topography is quite variable [1]. Wetlands account for $30 \%$ of the land use. Annual temperatures have been rising since the $1840 \mathrm{~s}$ which could contribute to higher runoff water flows and greater sedimentation [1]. Melting glaciers (Figure 6) add 29\% to the flow in the Tanana and White

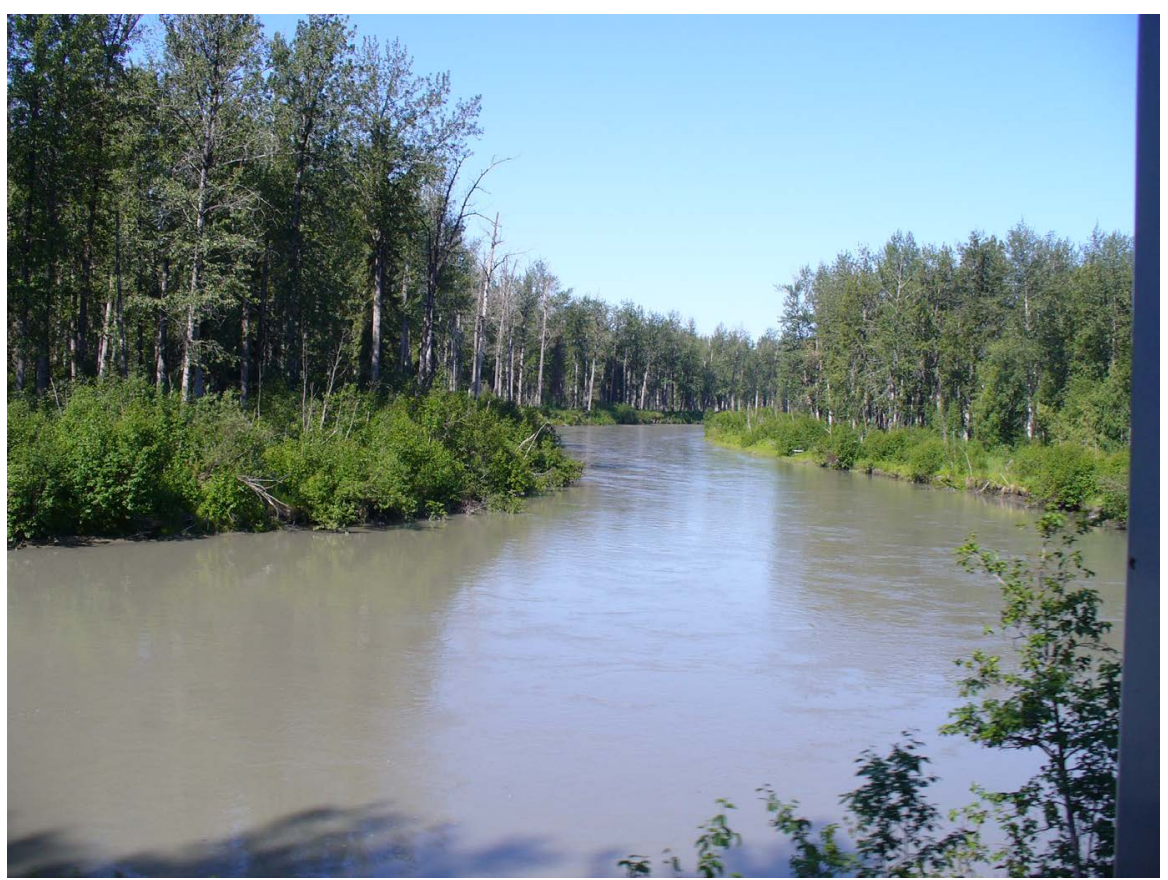

Figure 3. Forested floodplain with large river sediment load.

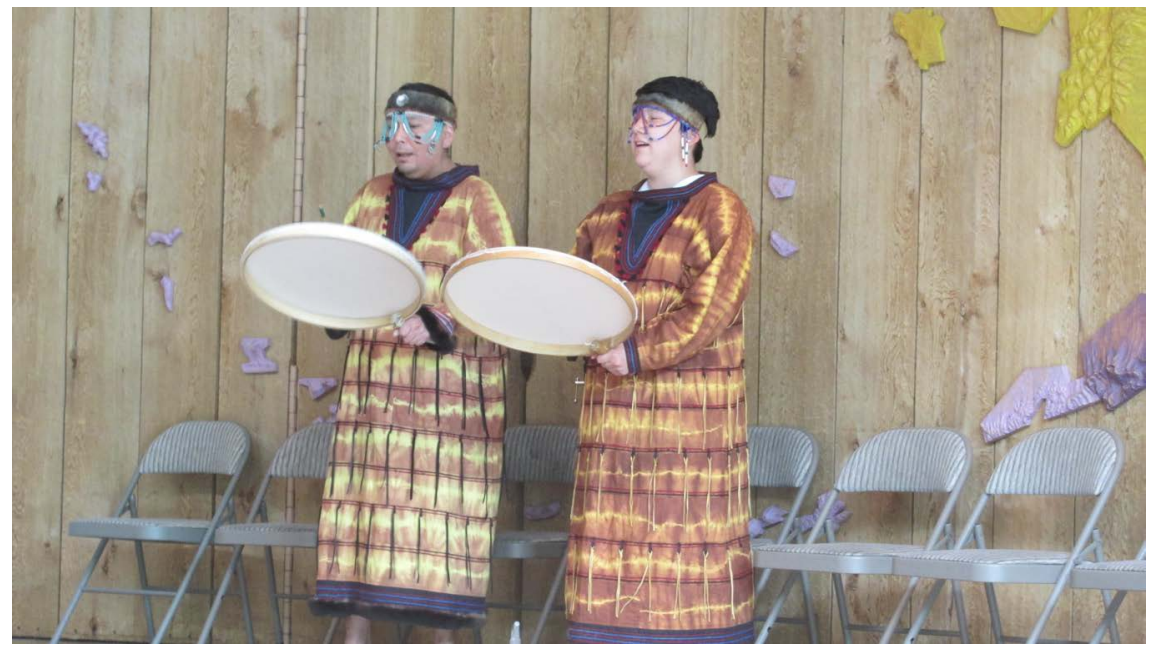

Figure 4. Native villagers talking to tourists at the Native American Center north of Anchorage. Photograph taken by Lois Wright Morton. 


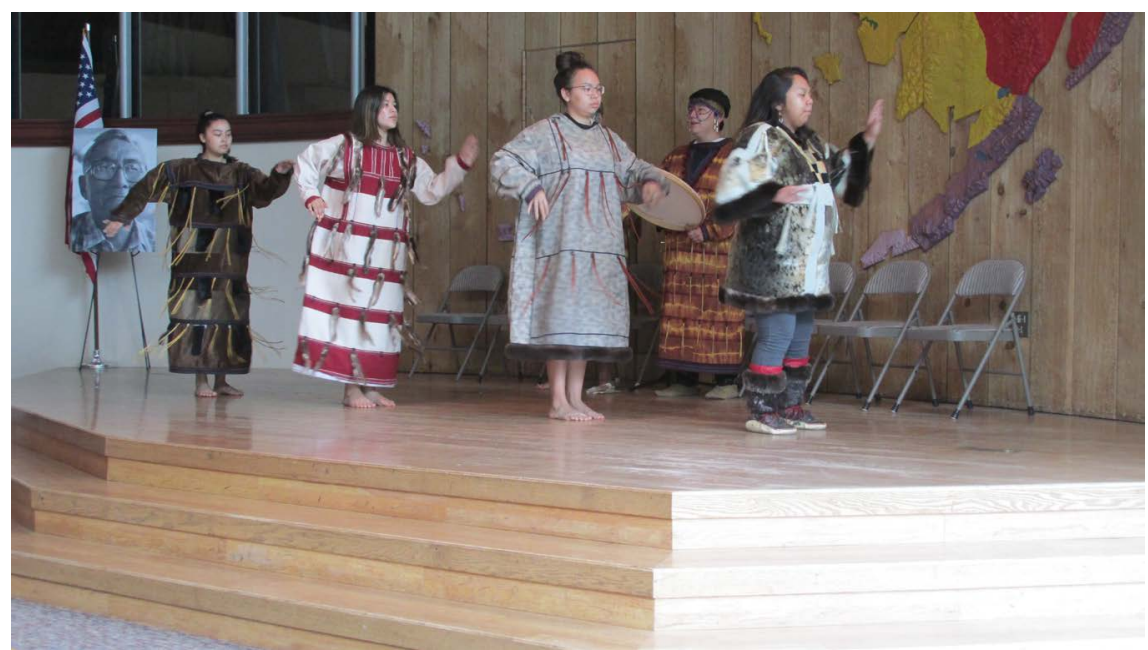

Figure 5. Native American village dancers at the Native American Center north of Anchorage, Alaska. Photograph taken by Lois Wright Morton.

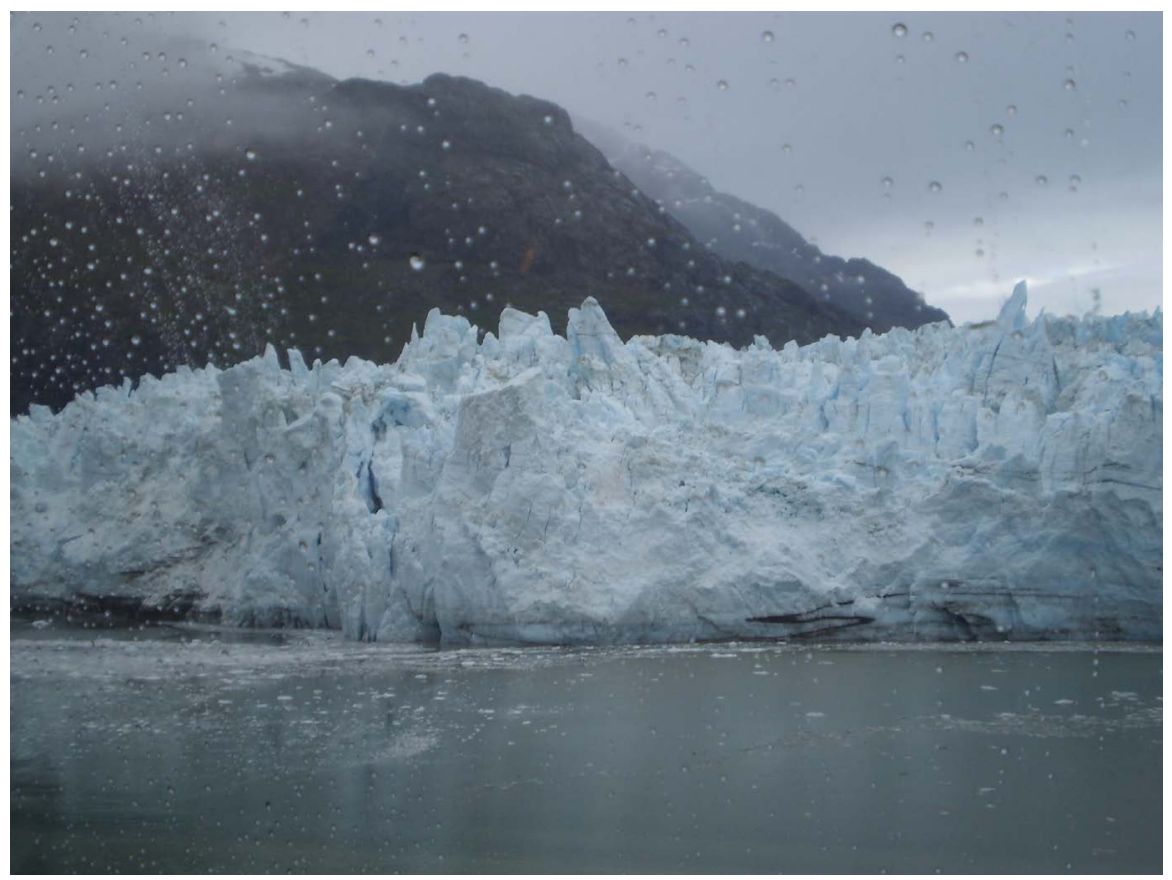

Figure 6. Glacial ice flows into water.

rivers (Figure 7). Most of the water flow is between May and September. Anthropogenic effects on the water quality of the Yukon River include pre-regulation mining (Figure 8), old Cold War military sites and atmospheric processes. The cumulative effects of man's activities on the Yukon River Basin cannot be made due to limited availability of water quality data [2]. With hotter and dryer conditions there has been an increase in forest fires and melting of the permafrost (Figure 9) which leads to increased water flows, sediment transport (Figure 10) and organic carbon transfer to Yukon River bottomlands, Yukon Flats, Yukon Delta (Figure 11) and the Bering Sea [1]. The primary objective was to document the sedimentation in the Yukon watershed with little accelerated soil ero- 
sion as a result of agriculture or urban development. The causes of soil erosion and sedimentation were permafrost, alpine glacial melting, gold mining, gas and oil drilling, pipeline construction (Figure 12), cold war military sites, forest fires and steep slopes.

\section{Study Site}

\subsection{Alaska Geological History}

The Cordilleran Ice Sheet was a major ice sheet that periodically covered much

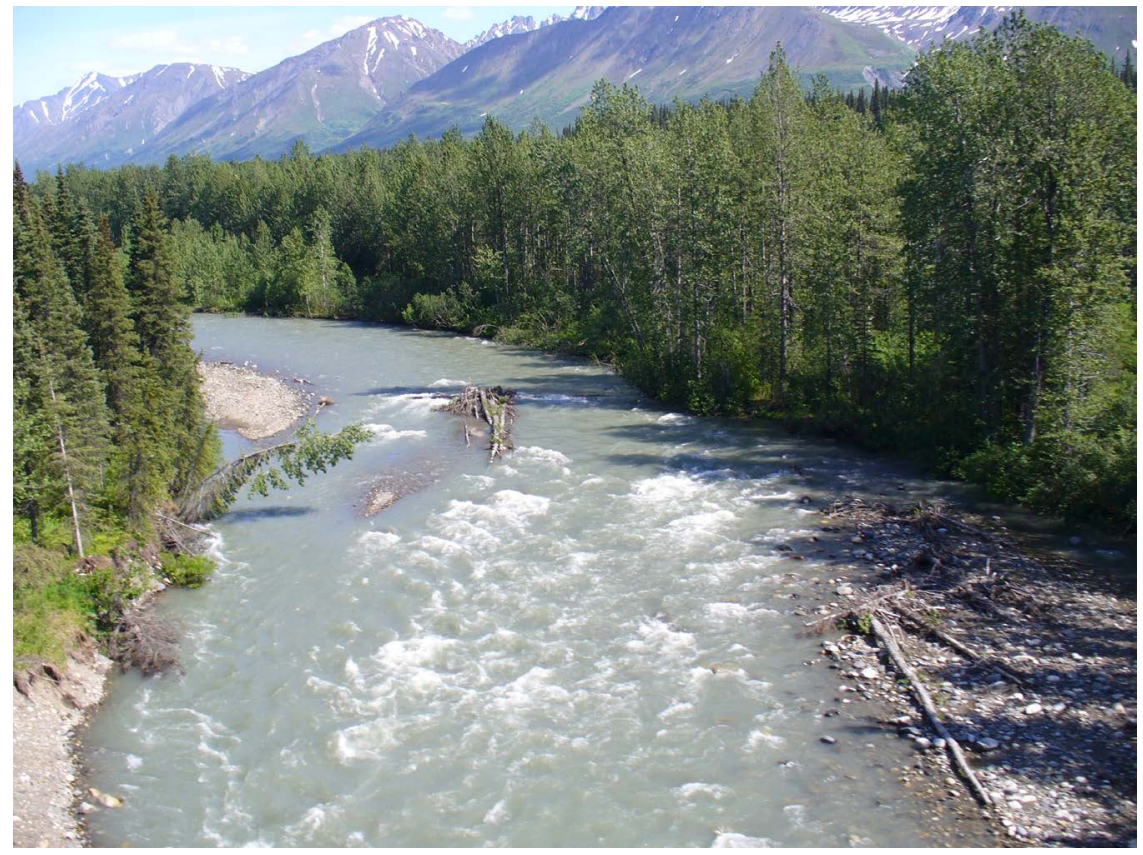

Figure 7. Fast moving river water in a valley southeast of Fairbanks.

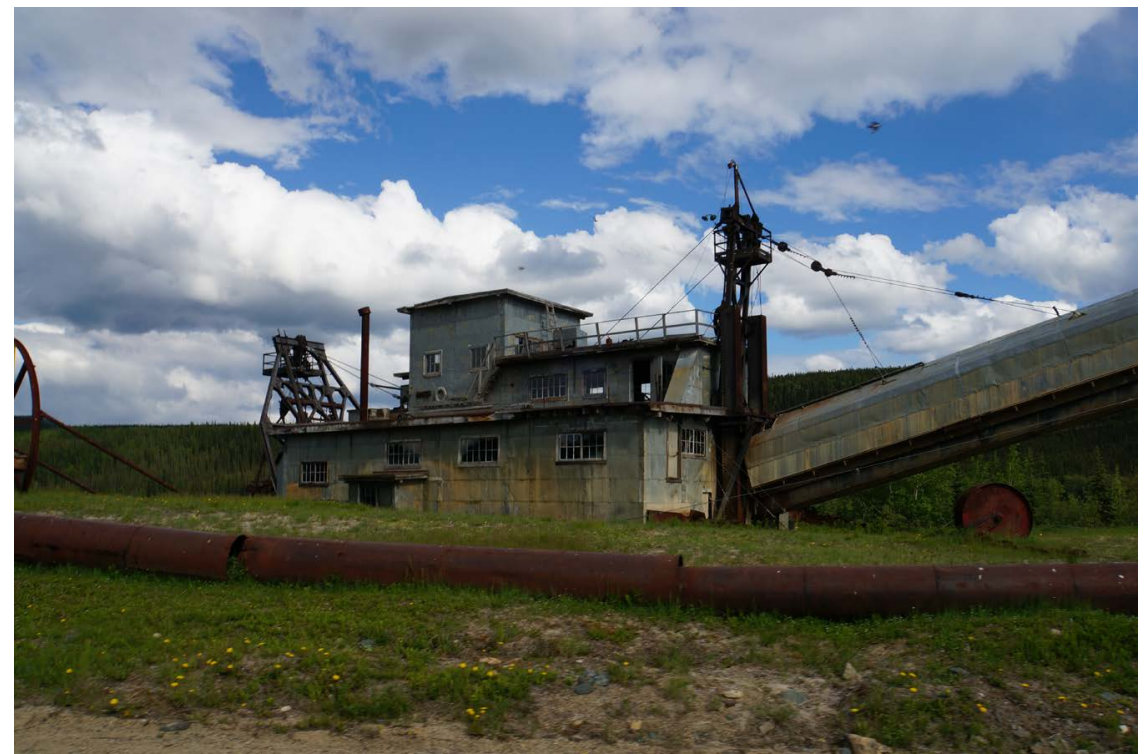

Figure 8. Old gold mining equipment in Chicken, Alaska. Photograph taken by Lois Wright Morton. 


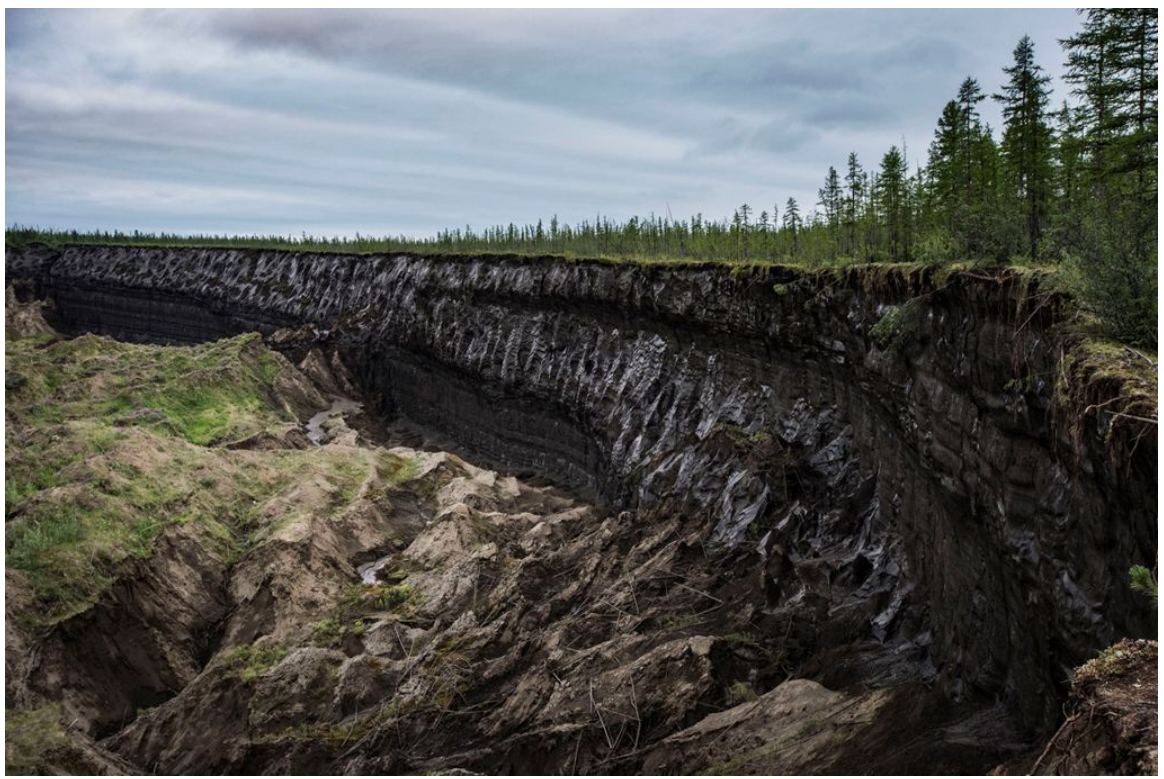

Figure 9. Wall of streambank sliding into a river with permafrost and peat exposed.

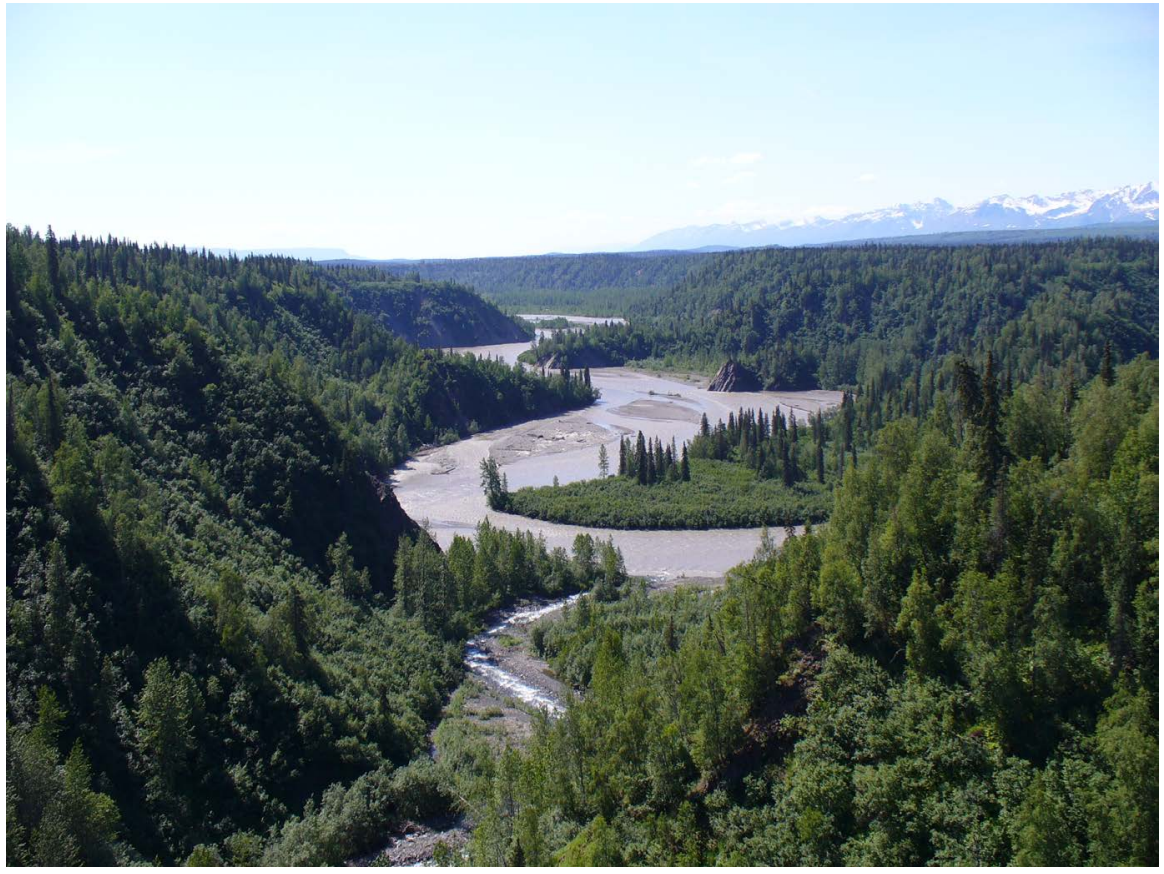

Figure 10. River sediment deposited on floodplain of an Alaska river.

of North America during the last 2.6 million years. The glaciers in the Yukon River Basin were mostly alpine glaciers (Figure 13) rather than continental glaciers due to insufficient moisture [2]. The climate varies widely as a result of the topography and the size of the Yukon River Basin. The precipitation over the entire basin ranges from $48 \mathrm{~cm}$ per year to $130 \mathrm{~cm}$ per year. The average temperature is 30 degrees $C$ in the summer and -40 degrees $C$ in the winter. Recent studies found annual temperatures have been rising since the 1840s which could contribute to higher runoff water flows and greater sedimentation. Natural 


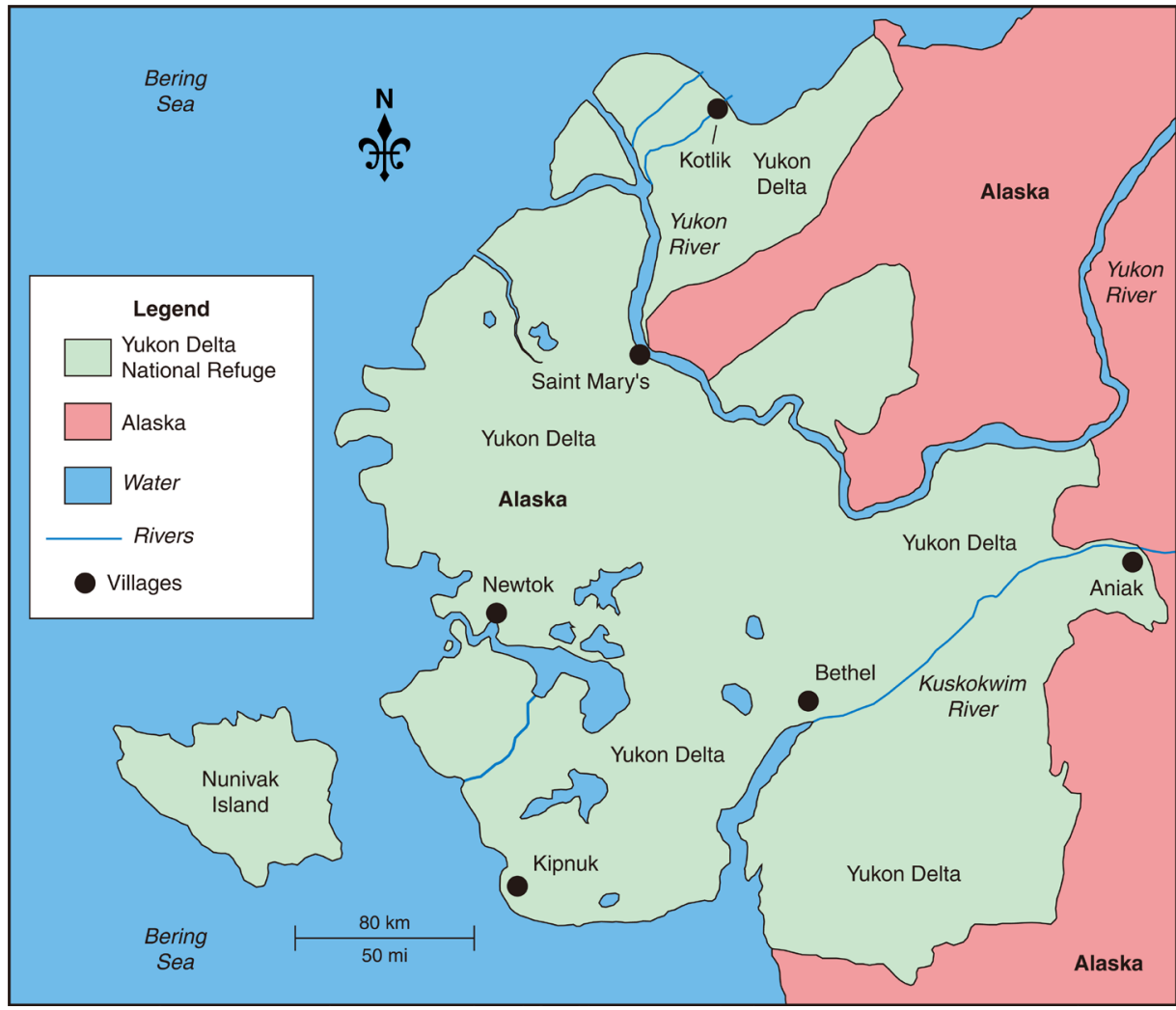

Figure 11. The Yukon Delta National Refuge of Alaska. Map by Mic Greenberg.

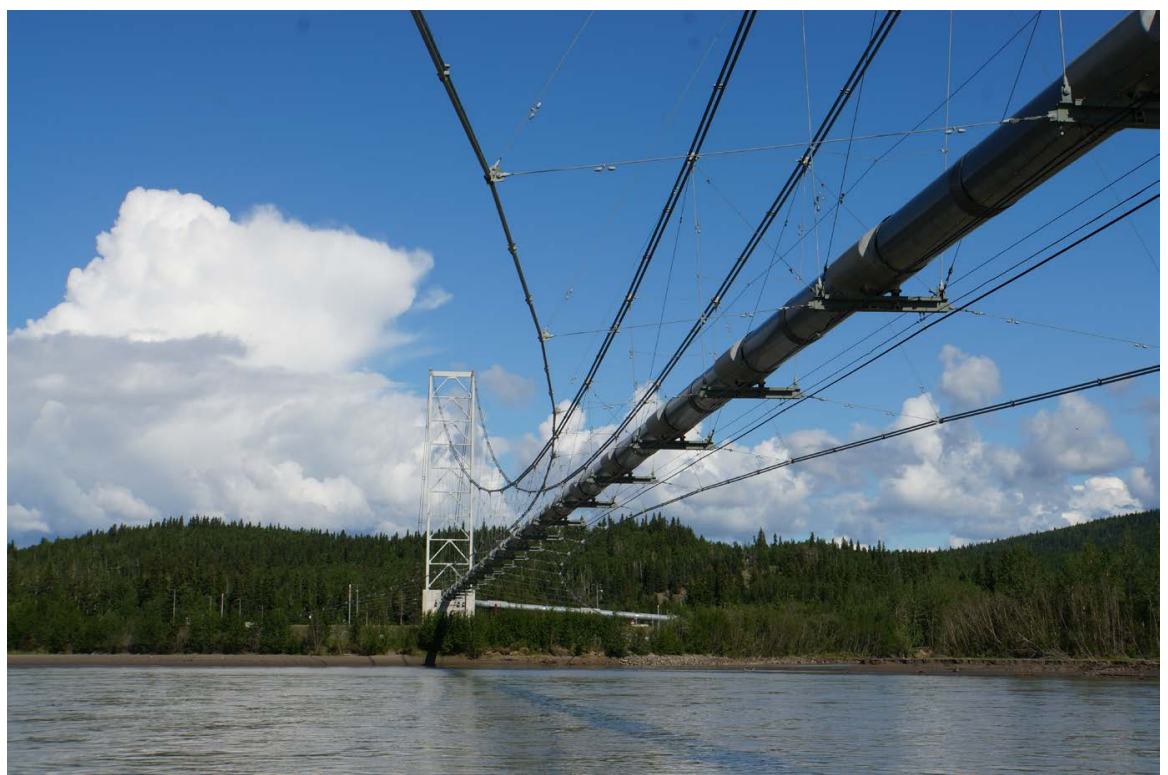

Figure 12. Alaska pipeline passing over the Tanana River east of Fairbanks, Alaska.

climate change is a serious concern [1].

A wide variety of rock types occur in the Yukon River Basin including sedimentary, igneous and metamorphic rocks. Several different land types occur including needle leaf forests (Figure 14), tall and short shrub lands (Figure 15), broadleaf forest, lichens, barren, wet herbaceous (Figure 16), dwarf shrub lands, 


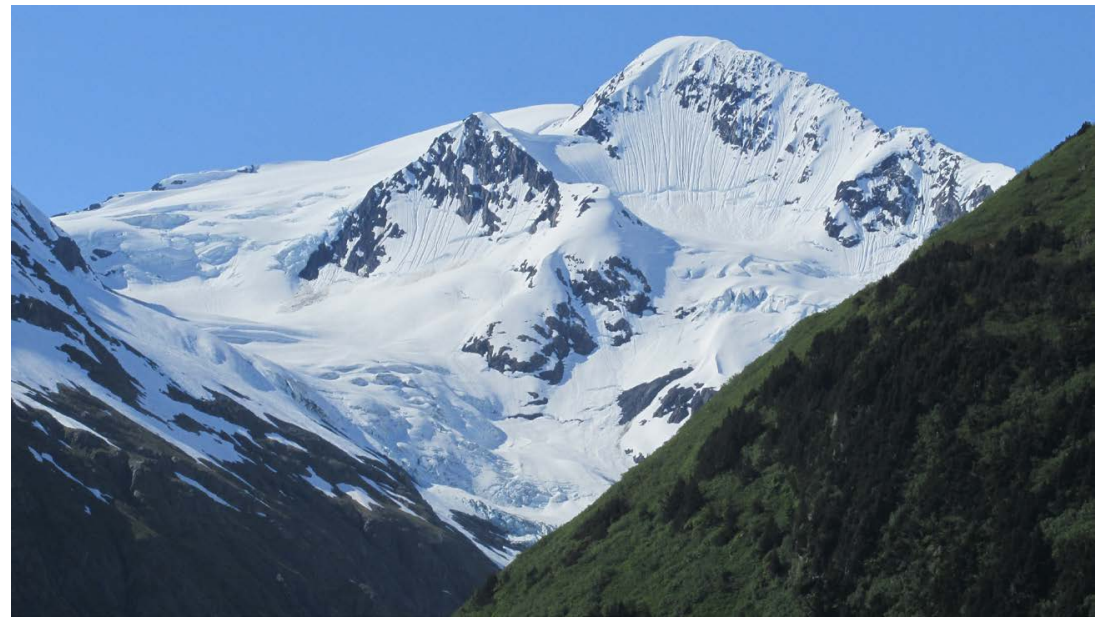

Figure 13. An alpine glacier near Portage, Alaska. Photograph by Lois Wright Morton.

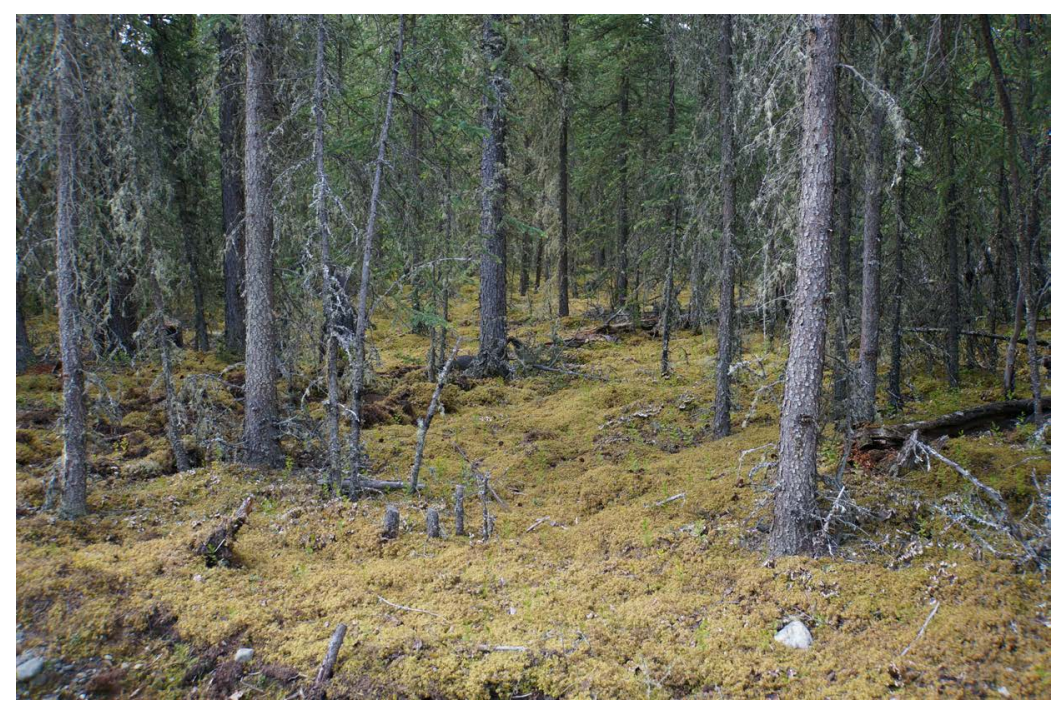

Figure 14. Forest near Chicken, Alaska. Adjacent areas are being cleared for cabins.

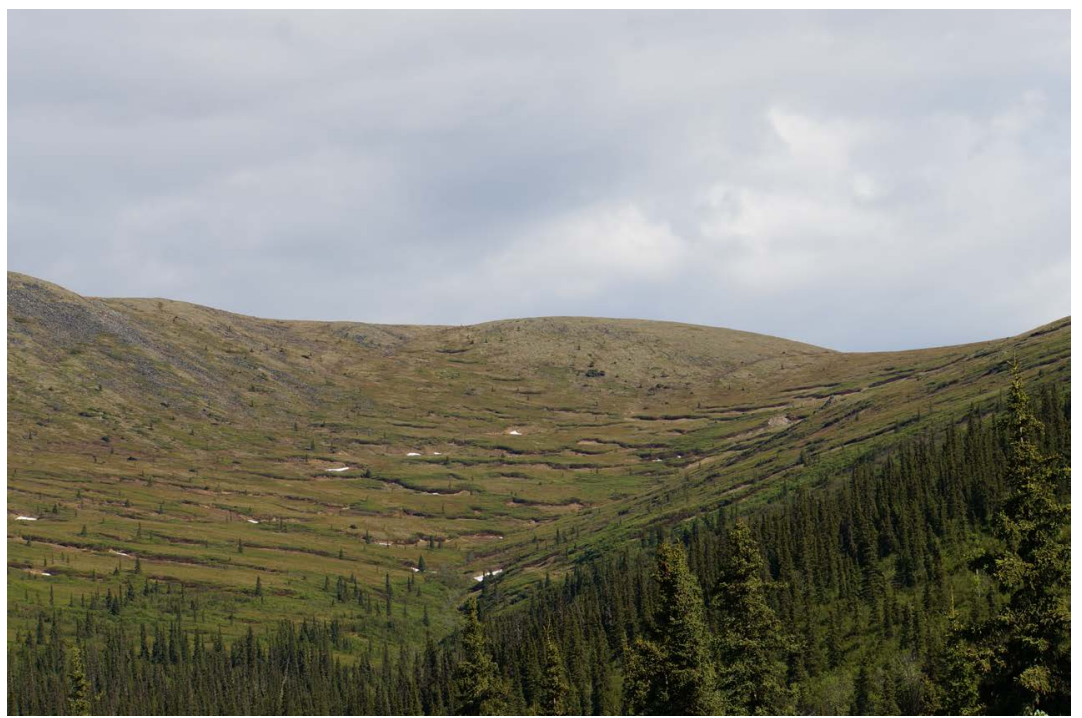

Figure 15. Short shrub lands on bedrock. Most of the soil has been eroded. 


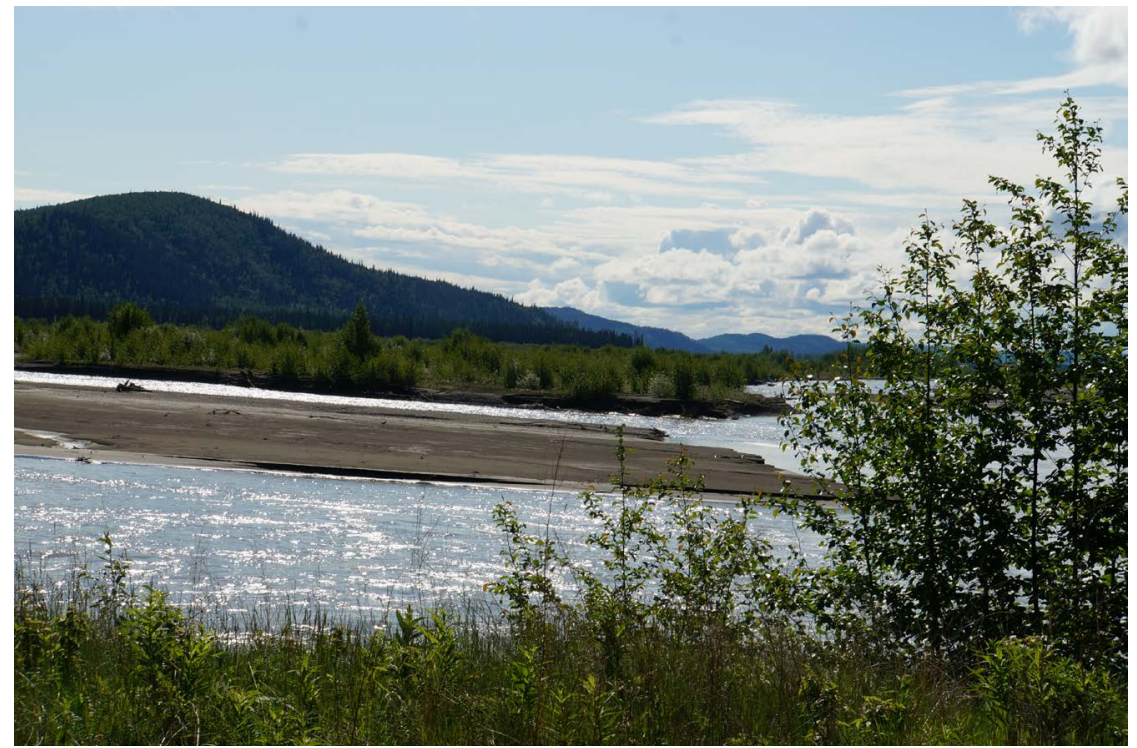

Figure 16. River sand bar habitat and wet herbaceous plants west of Circle, Alaska.

dry herbaceous, ice/snow and rivers, streams and lakes.

\subsection{Exploration of the Yukon River Basin}

The aboriginal people of the Yukon River Basin may be among the oldest known residents of North America. After crossing, by both boat and walking, Beringia or the land bridge that once linked Asia and America, these early people occupied Alaska and the western part of the Yukon Territory [2]. Those who did not trade with the coastal Tlingits of southeastern Alaska remained free of effects from other cultures until the $19^{\text {th }}$ century.

Interest in furs, not gold, lured the first outsiders to the Yukon. One of the earliest explorations of the Yukon Basin by Europeans was undertaken by Robert Campbell of the Hudson Bay Company. Beginning in the 1870s, early explorers established a number of trading posts up and down the Yukon River. In 1885, miners found placer gold on the Stewart River and in 1886, gold was discovered on the Fortymile River [2]. Additional discoveries were made in the Circle and Rampart areas in 1893. However, these first economically beneficial strikes in the Yukon River Basin were only a trickle compared to the tidal wave of miners that would come with the Klondike discoveries at Dawson City, Yukon Territory, Canada in 1897. At its peak in 1900, Dawson City (Figure 17) was home to as many as 25,000 people from every corner of the world. Although only a few struck it rich, the 1897 gold rush to the Klondike in the Yukon Territory led to commercial mining in the Yukon River Basin.

The construction of the Alaska Highway in 1942 (Figure 18), to provide a road link from the Lower 48 to Alaska through Canada as a defense measure during World War II, signaled an end to a way of life in the Yukon. Commercial river traffic ended a few years later. Gradually, a network of roads was constructed that today links many of the communities [3]. 


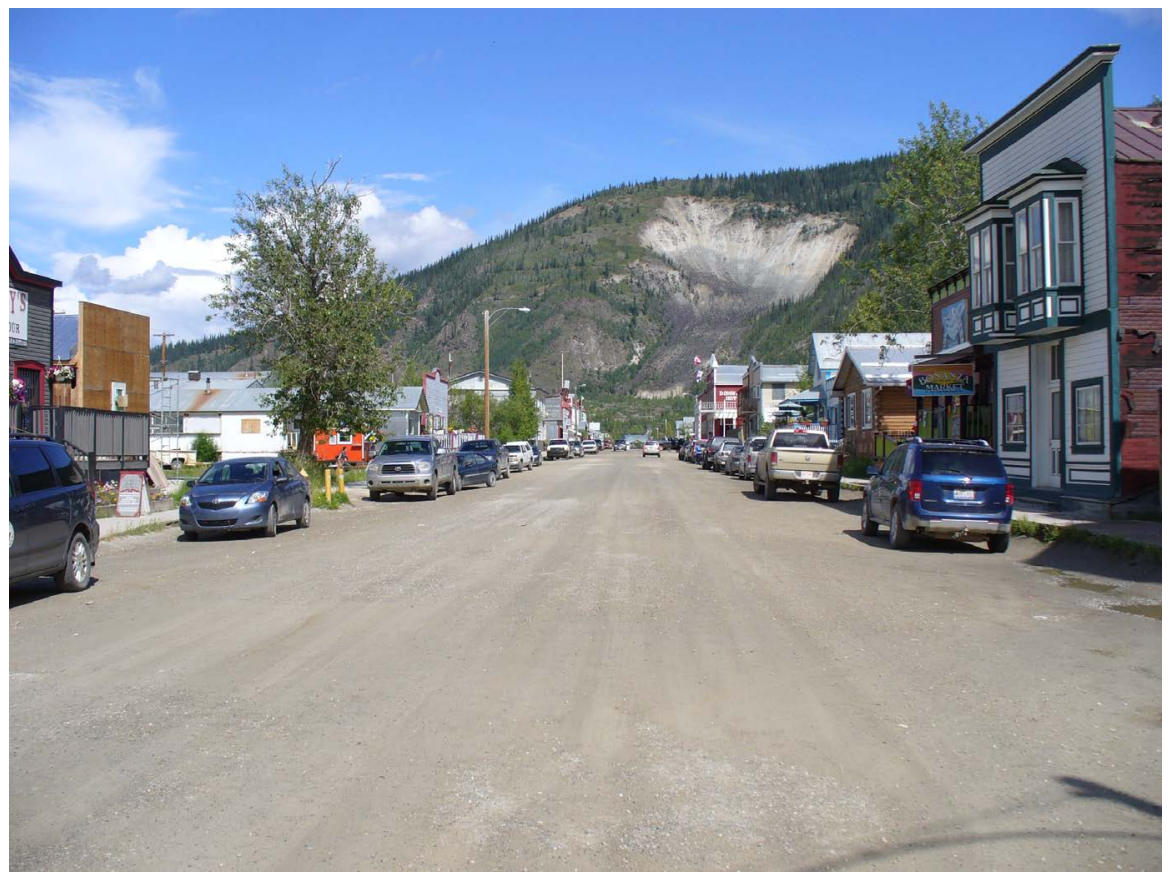

Figure 17. Dawson City, Yukon Territory of Canada. A massive land slide.

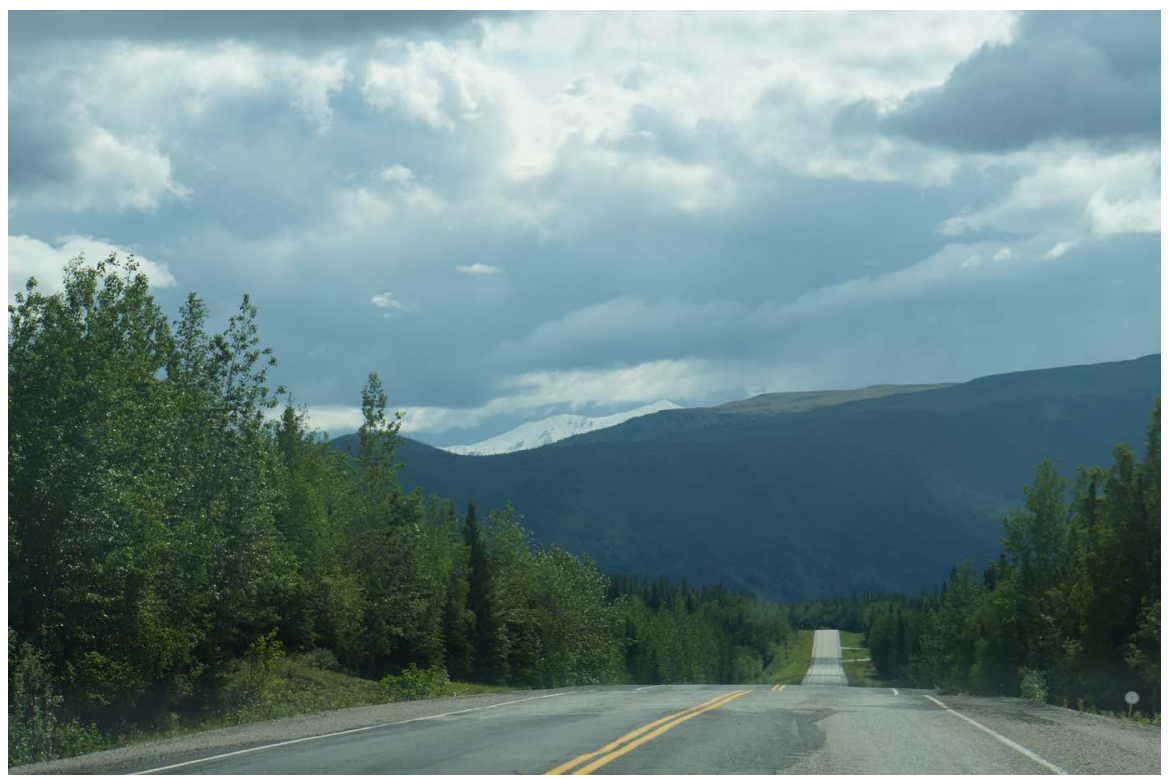

Figure 18. Alaska Highway through mountains with permafrost requiring patching. Photograph taken by Lois Wright Morton.

\subsection{Yukon Flats}

The Yukon Flats are centered on the confluence of the Yukon River, Chandalar and Porcupine Rivers in central Alaska. The watershed is approximately 28,500 $\mathrm{km}^{2}$ of wetlands, forest (Figure 14), bog and low-lying bottomlands located between the White Mountains to the south and the Brooks Range to the north. The Yukon Flats have approximately 40,000 small lakes, ponds and streams that are critical waterfowl habitat. The area is now mostly in the Yukon Flats National 
Wildlife Refuge. The Wildlife Refuge is located on both sides of the Arctic Circle and temperatures can vary from -57 degrees $\mathrm{C}$ in the winter to 35 degrees $\mathrm{C}$ during the summer.

A few thousand Alaska Natives and others live in the Yukon Flats watershed within a few small villages and seasonal settlements including hunting cabins [2]. The region contains large deposits of crude oil and natural gas. This has led to a conflict between protecting wildlife and drilling interests. A proposed land trade was made in 2008 between private sector land owners and the federal government but it did not happen; however, trade talks are still ongoing.

\subsection{People and Land}

In the Canadian part of the Yukon River Basin, Whitehorse is the center of population with just over 23,000 residents in 1998 [4]. The town of Dawson City (Figure 17) has just over 2000 residents. The remaining towns have populations ranging from 100 to 1000 residents. In Alaska, the greater Fairbanks area (Fairbanks and North Pole) is the center of population and had approximately 84,000 residents in 1996 [3]. About 12,000 other residents are located in 43 villages scattered across the Yukon River Basin from the Canadian border to the mouth of the Yukon River. In the Yukon River Basin: the Yupik Eskimos live along the Bering Sea coast and inland waterways. The Athabaskan Indians occupy the remainder of the Yukon River Basin.

In the Alaska part of the Yukon River Basin, about 68 percent of the land is owned by the Federal government (Figure 11). Four national parks cover 10 percent of the area, 8 wildlife refuges include over 32 percent of the area, and Bureau of Land Management (BLM) land composes 22 percent. The U.S. military and Native corporations each own approximately 1 percent of the land. The Canada segment of the Yukon River Basin includes parts of two Canadian National Parks, Vuntut and Kluane, in addition to several habitat protection areas. Atlin Provincial Park is located near the headwaters of the Yukon River. These lands compose about 9 percent of the land area of the Canadian Yukon.

\subsection{Yukon-Kuskokvim Delta}

The Yukon-Kuskokwim Delta is where Yukon and Kuskokwim rivers flow into the Bering Sea. The delta is $129,500 \mathrm{~km}^{2}$ and located on the west coast of Alaska [1]. It is larger than the Mississippi River Delta. The delta consists of tundra (and has approximately 25,000 residents). Eighty five percent are Alaska Natives (Figure 19) living primarily in Bethel, Alaska. Most residents have cash incomes below the federal poverty level as a result of their subsistence lifestyle of fishing (Figure 20), hunting (Figure 21) and edible plant consumption. GPS is of little value since there are no connecting roads to the rest of Alaska. Travel is by plane, dog sled (Figure 22) or by snow machines in the winter and river boats (Figure 23) and small craft (Figure 24) during the summer. Villages such as Fort Yukon are still not connected by a highway and cargo and supplies have to 


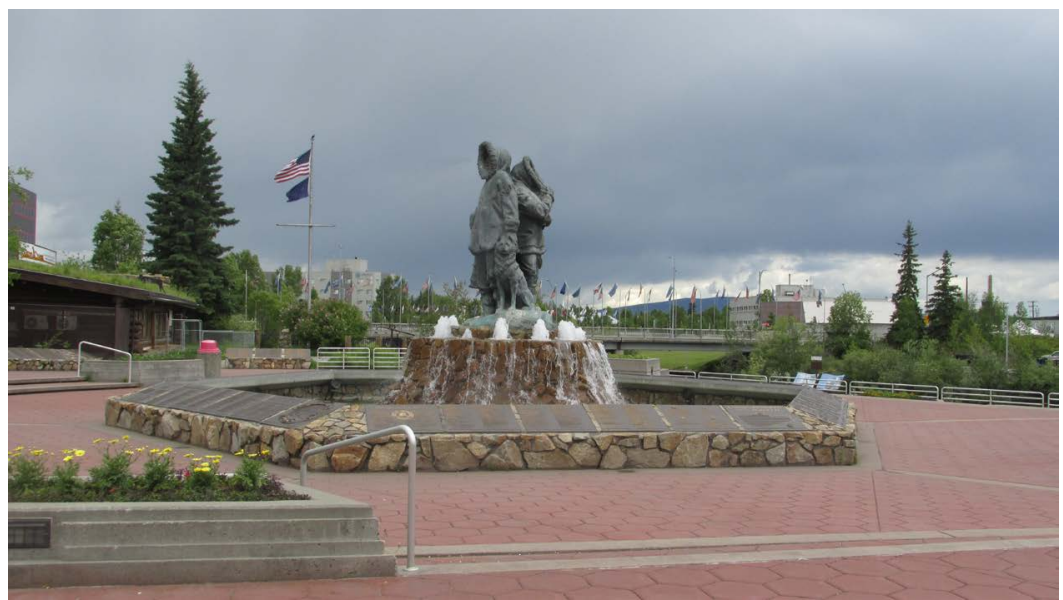

Figure 19. Native American statue in a park in Fairbanks and along the Chena River, an urban river.

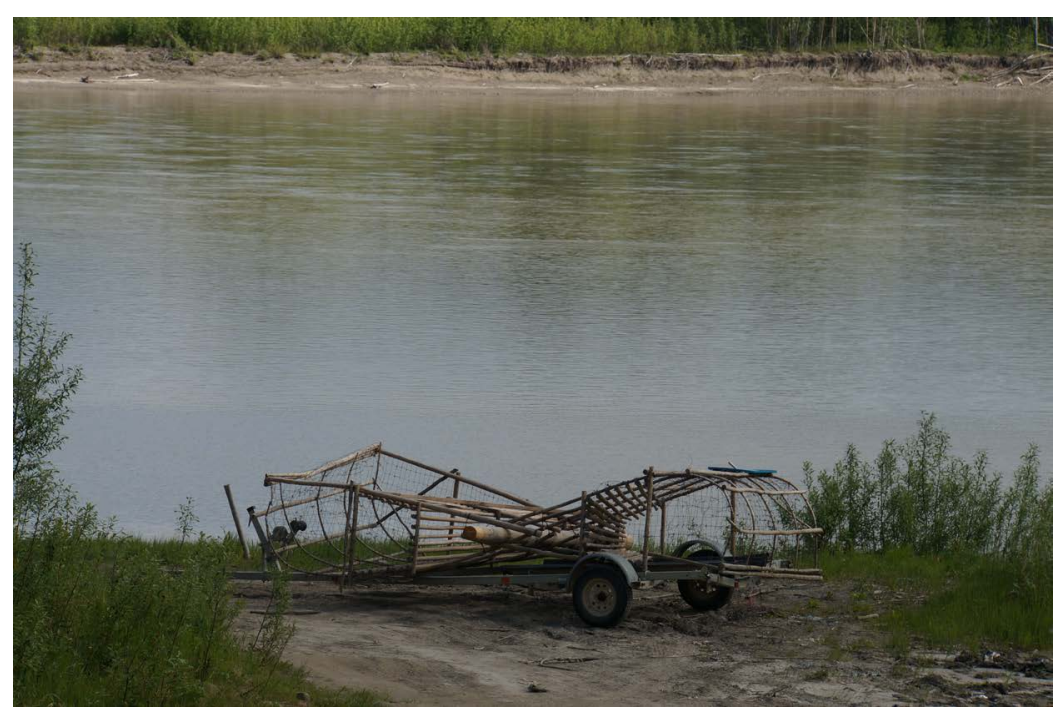

Figure 20. Portable fish traps next to the Yukon River for transport to Native Americans downriver who are the only fisherman who can use the traps.

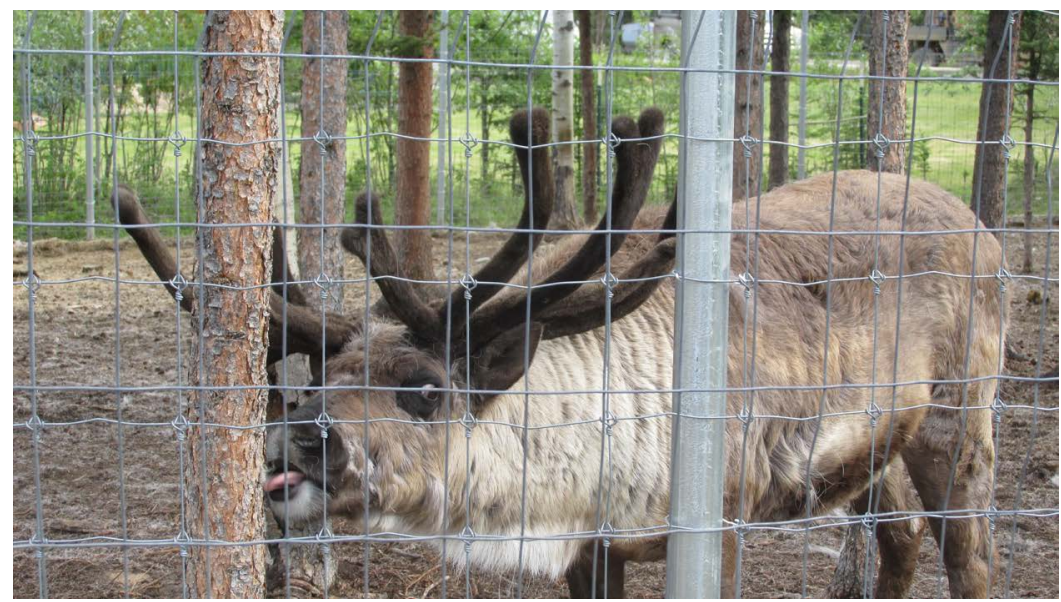

Figure 21. Friendly reindeer greeting the tourists at a wilderness park near Denali National Park, Alaska. 


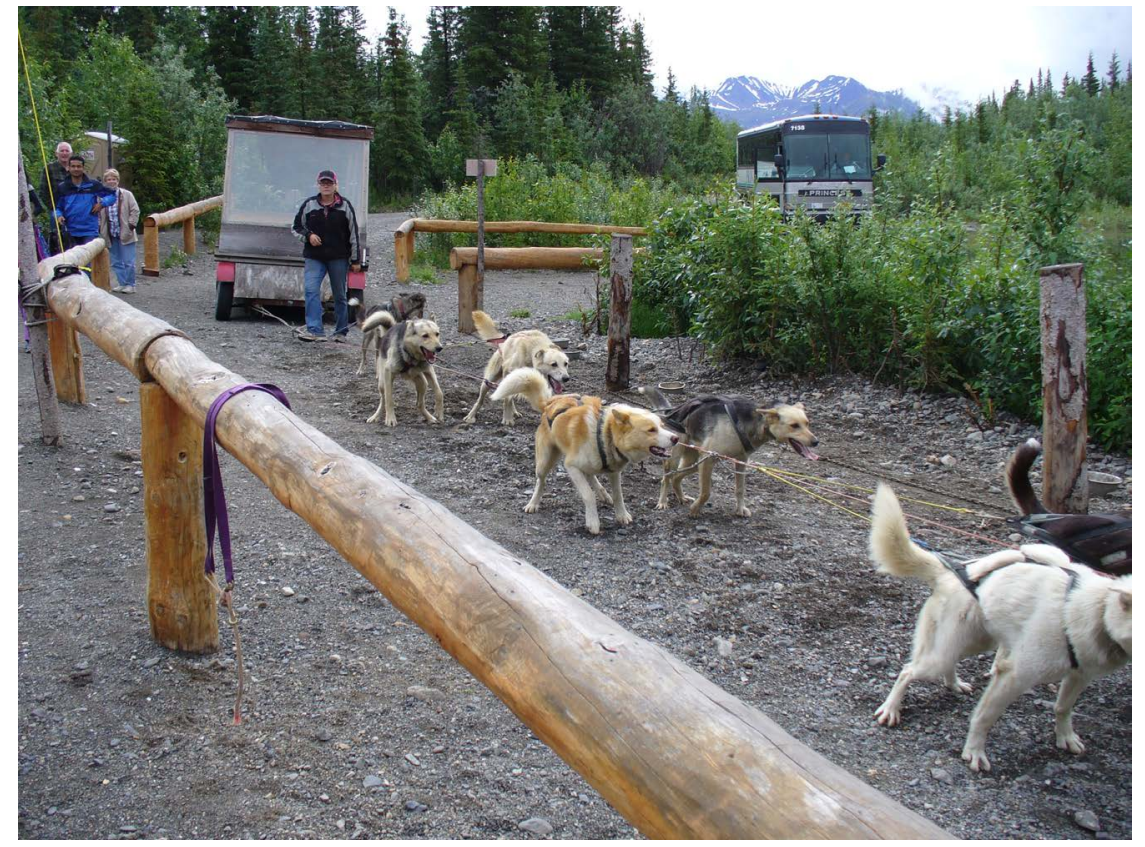

Figure 22. Iditarod Alaskan Husky dog sled team during a summer workout. Athabaskan tribal mushers, Alaska.

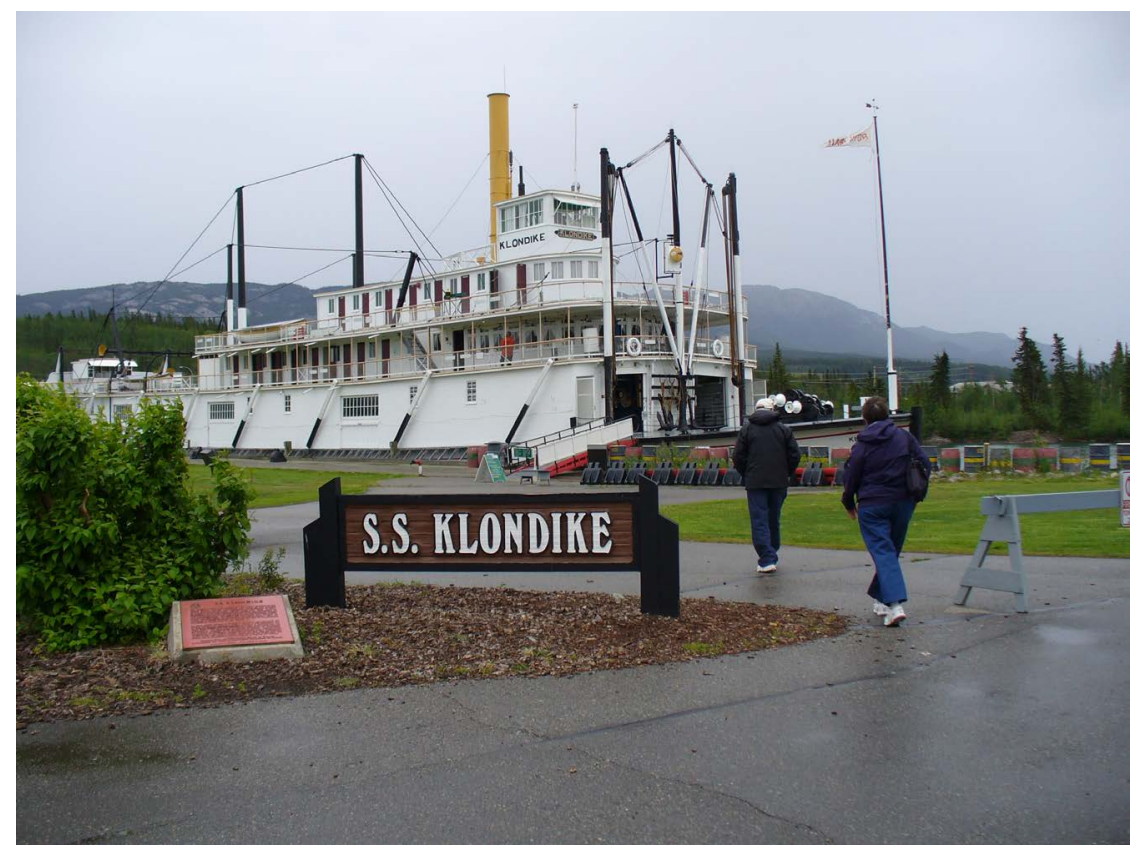

Figure 23. SS. Klondike steamer paddle wheel boat in dry dock in Whitehorse, Yukon Territory, Canada.

be trucked to Circle, stored outside at a trading post on the banks of the Yukon River (Figure 25) and then loaded on boats or barges for the downriver journey to Fort Yukon (Figure 26).

\subsection{Soils of the Yukon River Basin}

In the Yukon River Basin, the type of parent material, climate and relief have 


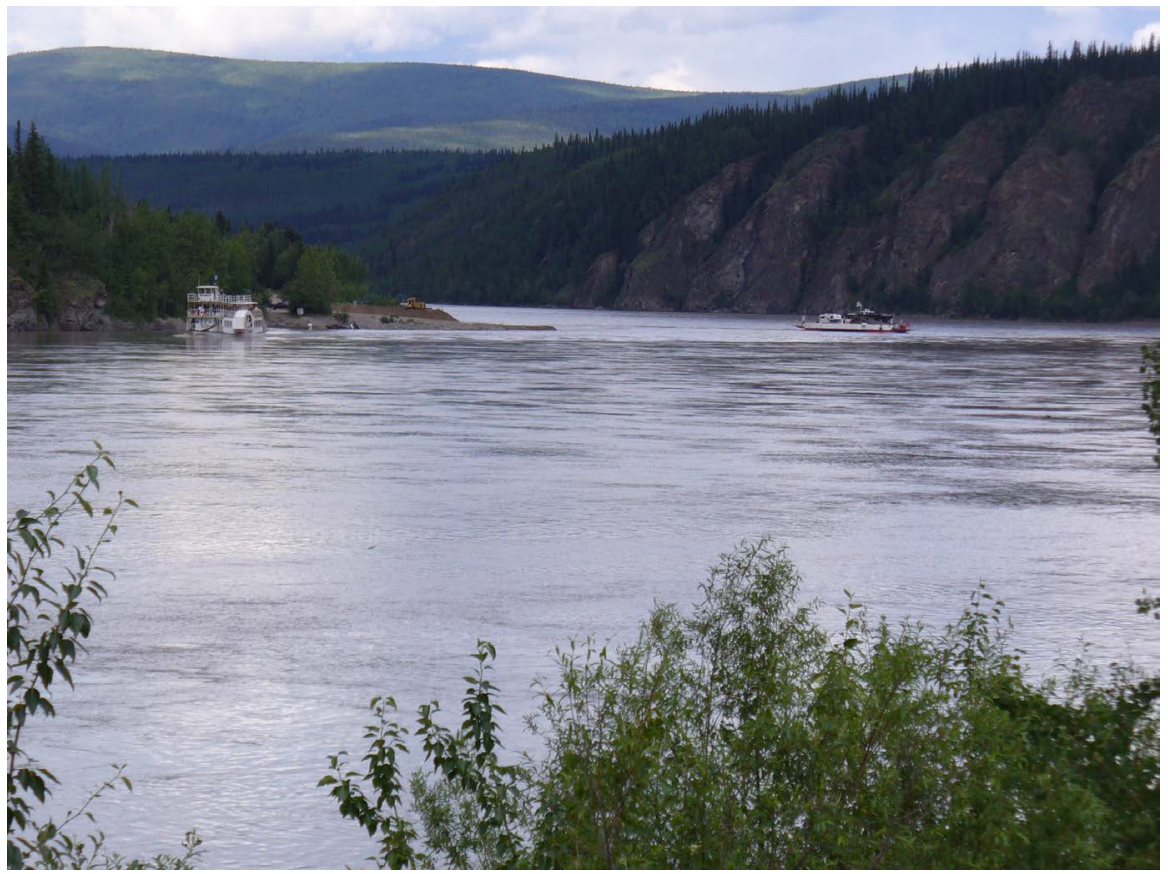

Figure 24. Paddle wheel boat and car ferry crossing the Yukon River, Dawson City, Yukon Territory, Canada.

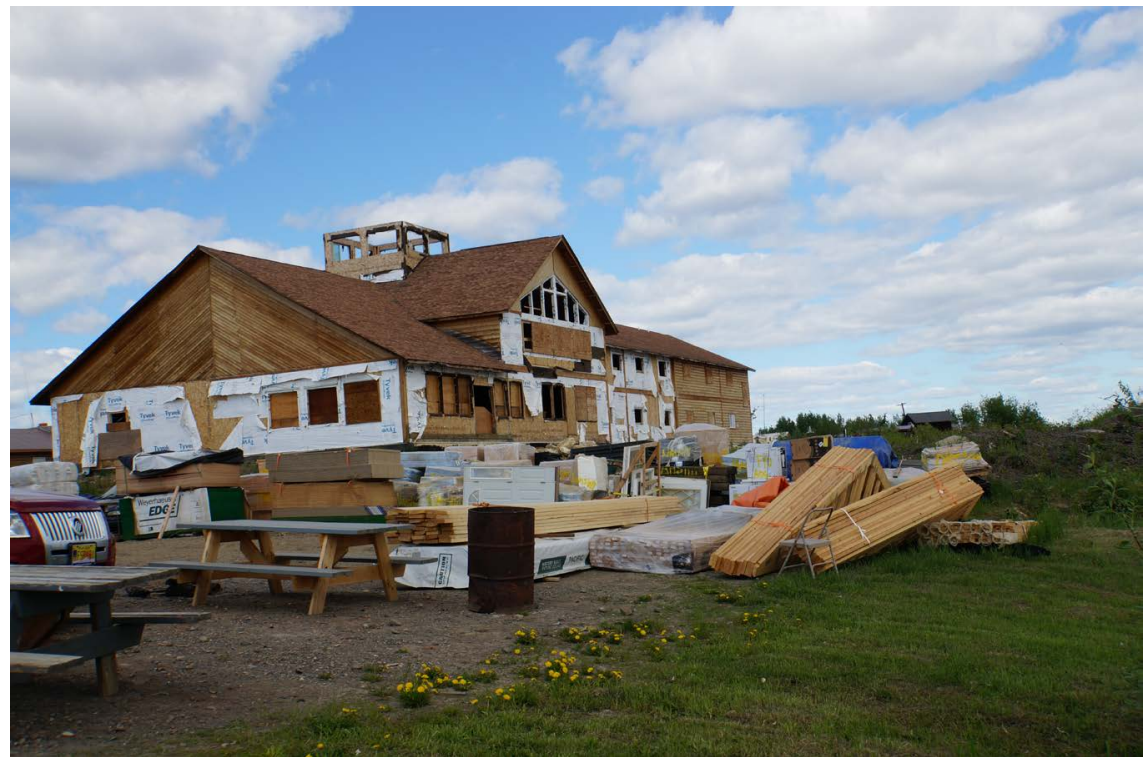

Figure 25. The trading post and harbor supply storage area for shipment in Circle, Alaska on the Yukon River. Cargo will be shipped downriver to Fort Yukon. There are no roads to Fort Yukon.

been the most dominant soil forming factors. Soil types can affect water quality as precipitation infiltrates the soil. Minerals are weathered from the parent materials and carried into streams. Slope gradient and soil type are factors that affect the amount of soil erosion, transport and sediment deposition.

The soils of the Yukon River Basin are classified in 6 of the 12 Order categories [5]. These include Entisols, Inceptisols, Mollisols, and Spodosols soil orders 
[1] and the new order, Gelisols, for permafrost soils. Gelisols have permafrost within about $1 \mathrm{~m}$ of the soil surface and/or have gelic materials within about $1 \mathrm{~m}$ and permafrost within $2 \mathrm{~m}$. Gelic materials are mineral or organic soil materials that have evidence of frost churning in the seasonal thawed area or upper part of the permafrost. Permafrost (Figure 27) is defined on the basis of soil temperature (continually at or below 36 degrees $C$ for 2 or more years [6]) and not the presence of ice in the soil. One other area, rough mountainous lands, are not classified since they do not have sufficient soil to grow plants.

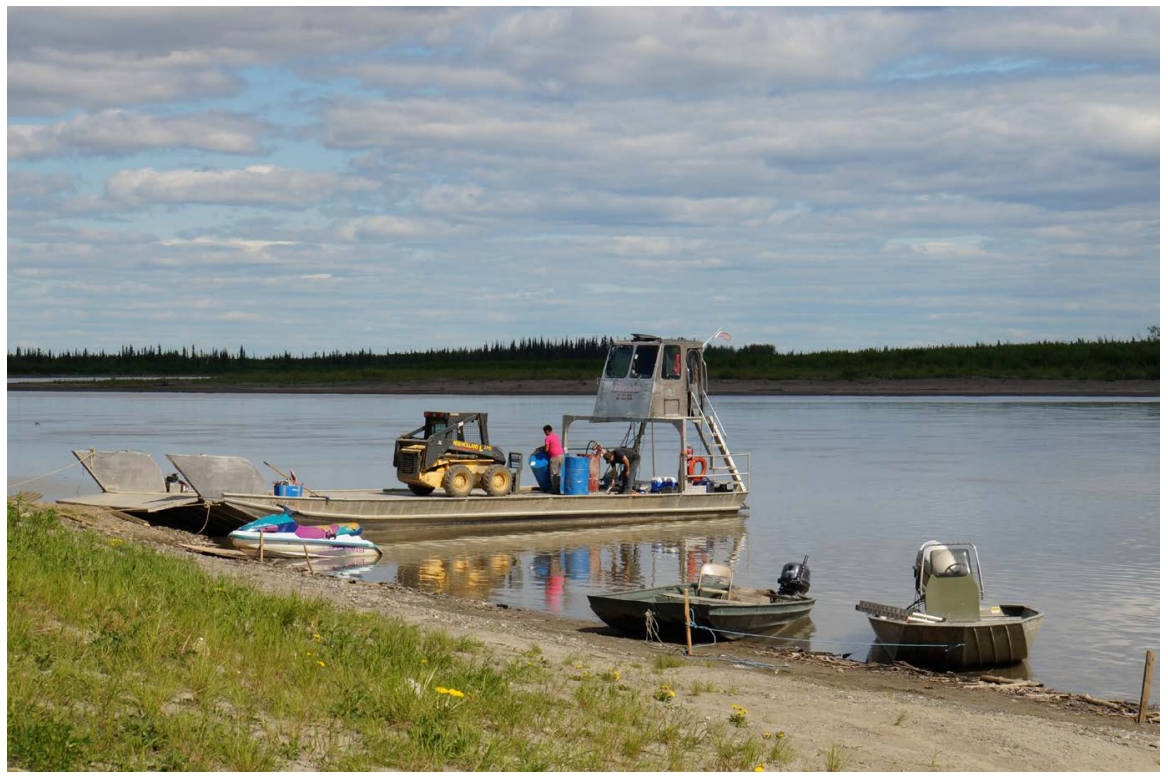

Figure 26. Cargo and supplies and cargo being loaded at Circle for the journey downriver to Fort Yukon.

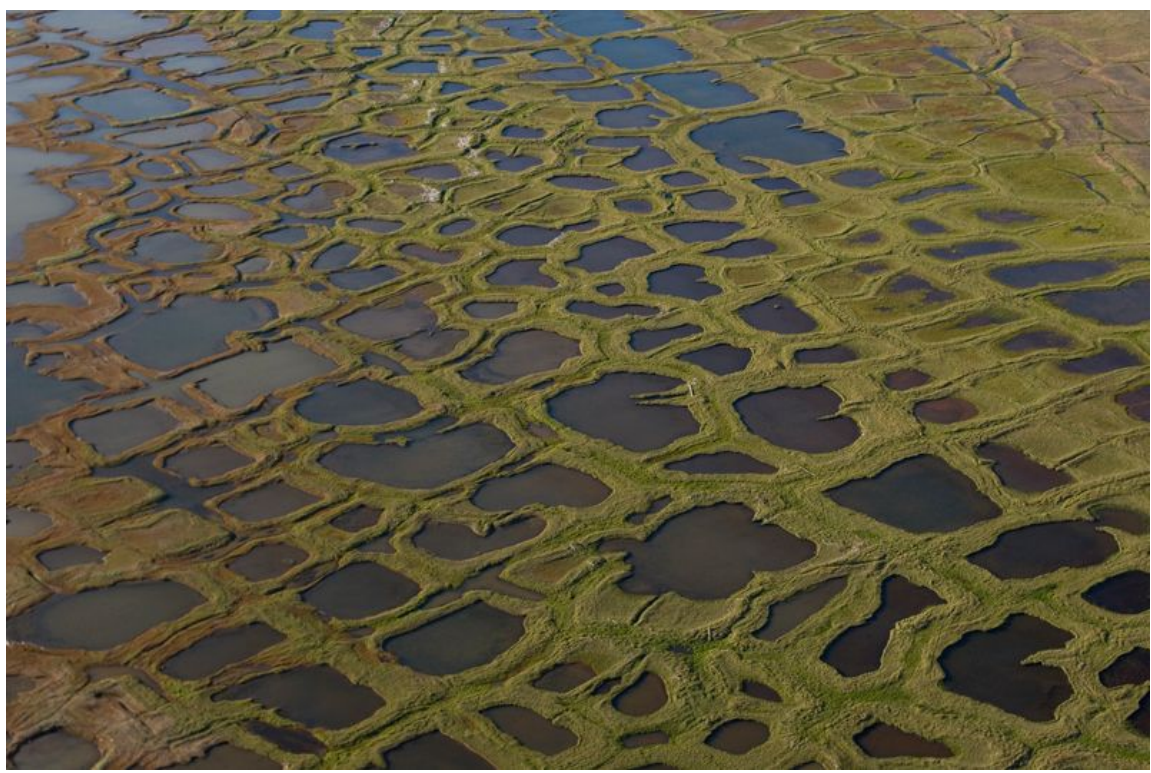

Figure 27. Permafrost pattern ground created by melting permafrost which re-freezes and expands as ice. Each polygonal unit expands and pushes against the next unit which results in an upward force. 
Entisols are soils with little soil horizon development on glacial outwash or alluvium in the Yukon River Basin. Inceptisols are recently developed soils with a greater degree of soil horizon formation than Entisols. Mollisols are primarily thick, dark and soft mineral soils. They occur primarily in parent material derived from limestone or other basic rocks (Figure 28) including basalt (Figure 29). The only area where Mollisols are found is north of the Yukon Flats in northcentral

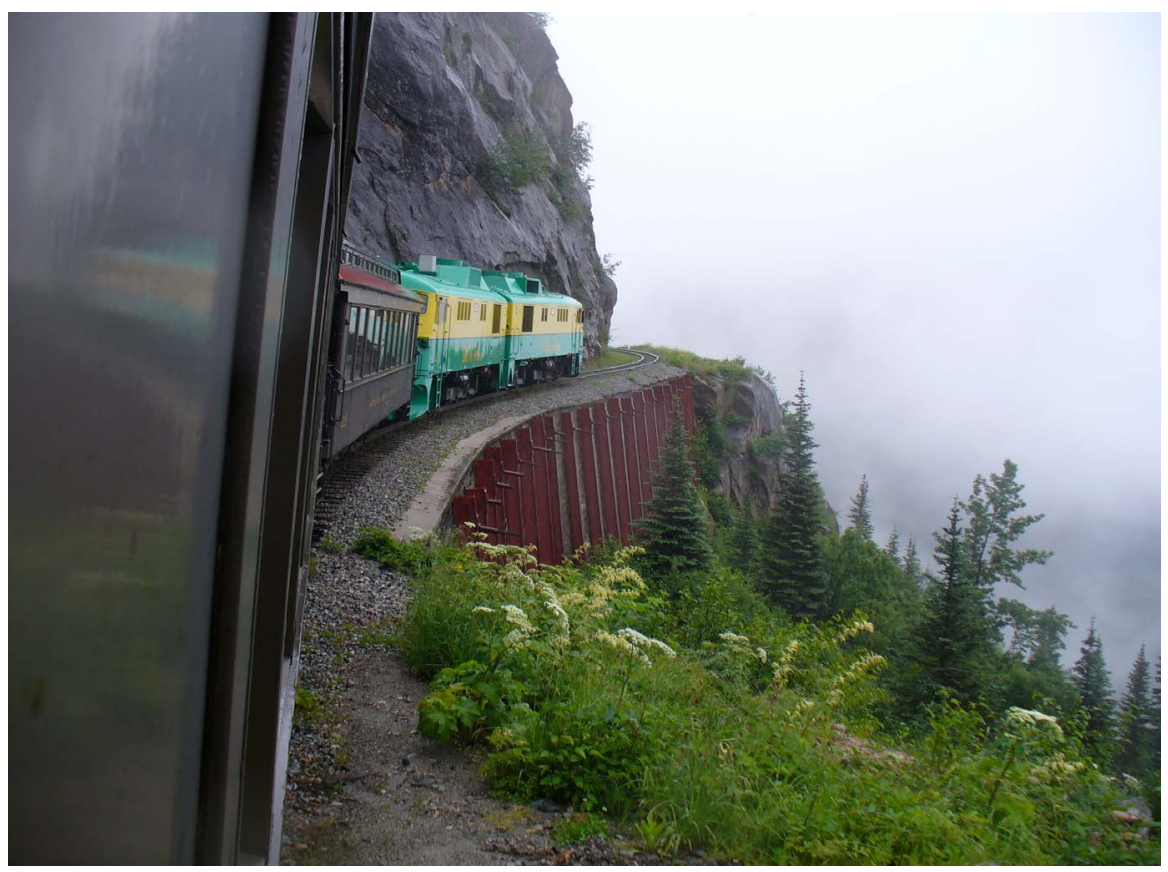

Figure 28. White Pass train and Yukon Railroad rolling through a solid bedrock cut, Tunnel Mountain at mile marker 16.0 which has a $690 \mathrm{~m}$ elevation.

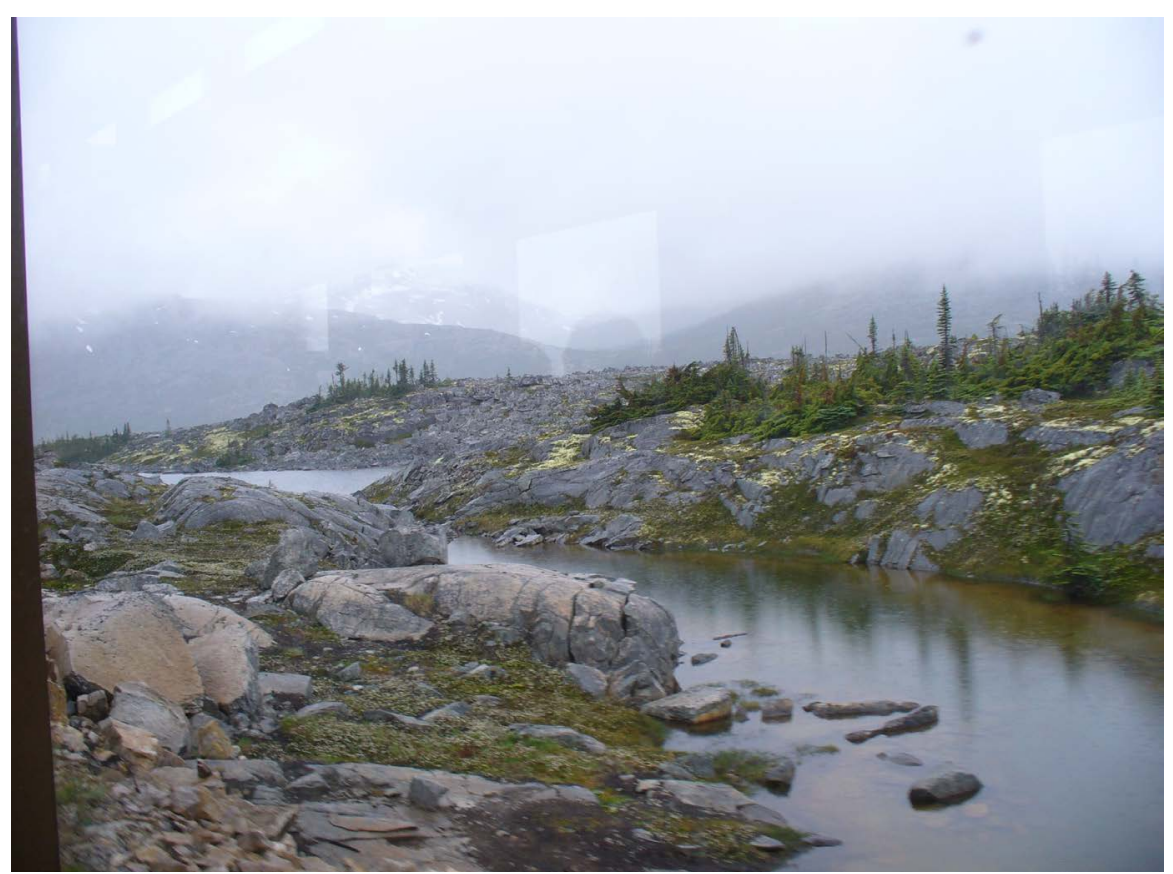

Figure 29. Shallow to rock soils with few shrubs and trees. 
Alaska. Spodosols have light-colored surface horizons with organic and aluminum-rich subsurface horizons.

\subsection{Peatlands}

Peatlands are also expected to be impacted by natural global climate change. Peat is made up of decomposing organic material, and so is very rich in carbon. It consists of $90 \%$ water and $10 \%$ plant matter, and is mostly found at the high latitudes of the northern hemisphere, both at the surface and below. Some of this peat is found underneath the permafrost layer (Figure 9), which means the carbon it harbors could be released to the atmosphere by microbes the permafrost should melt.

\subsection{Permafrost}

Permafrost is soil, rock or sediment that is frozen for more than two consecutive years. In areas not overlain by ice (Figure 29), it exists beneath a layer of soil, rock or sediment, which freezes and thaws annually and is called the "active layer." In reality, this means that permafrost occurs at a mean annual temperature of $-2^{\circ} \mathrm{C}$ or colder. Active layer thickness varies seasonally. The extent of permafrost varies with the climate: in the Northern Hemisphere today, $24 \%$ of the ice-free land area, equivalent to 19 million $\mathrm{km}^{2}$ [7], is more or less influenced by permafrost. Of this area slightly more than half is underlain by continuous permafrost, around 20 percent by discontinuous permafrost, and a little less than 30 percent by sporadic permafrost [8].

\subsection{Seasonal Melting of the Permafrost}

During summer in the Arctic, the soils warm fast and frozen soils start to thaw (Figure 30 ). When the ice layer melts, the soil organic carbon-rich soil oozes

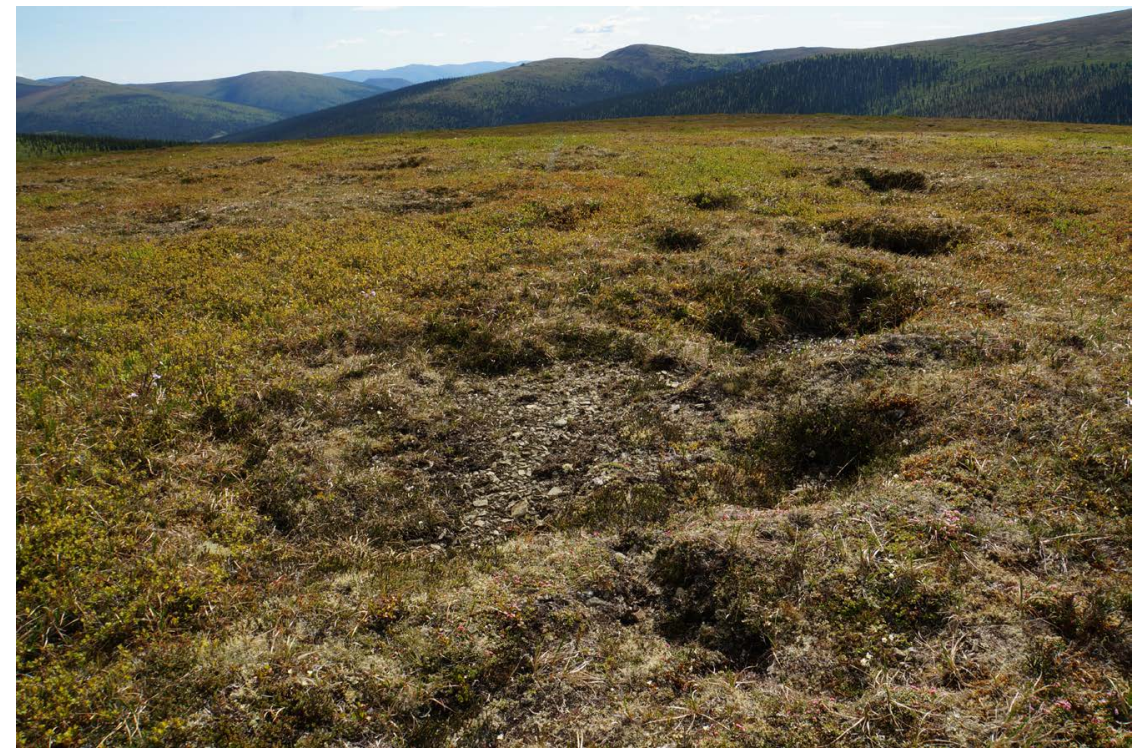

Figure 30. Permafrost sink holes in tundra. Photograph taken by Lois Wright Morton. 
from permafrost layer. As the temperature of the ground rises above freezing, microorganisms break down organic matter in the soil [9]. Greenhouse gases, including carbon dioxide, methane and nitrous oxide, are released into the atmosphere. Soils in the permafrost region hold twice as much carbon as the atmosphere does-almost 1600 billion $\mathrm{mt}$ [10]. Some of the soil organic matter is decomposed by the microorganisms and carbon dioxide is released into the atmosphere.

\subsection{Carbon Cycle in Permafrost}

The permafrost carbon cycle deals with the transfer of carbon from permafrost soils to terrestrial vegetation (Figure 31 ) and microbes, to the atmosphere, back to vegetation, and finally back to permafrost soils through burial and sedimentation due to cryogenic processes. Some of this carbon is transferred to the ocean and other portions of the globe through the global carbon cycle (Figure 32). The cycle includes the exchange of carbon dioxide and methane between terrestrial components and the atmosphere, as well as the transfer of carbon between land and water as methane, dissolved organic carbon, dissolved inorganic carbon, particulate inorganic carbon and particulate organic carbon [11].

\subsection{Methane}

In moist areas, most of the emissions will be of methane, a greenhouse gas that has 20 to 25 times more warming power than carbon dioxide. As the ground warms, methane will either be released directly into the atmosphere or bacteria will break it down into carbon dioxide, which will then be released. If areas of thawed permafrost exist at depth between frozen layers (Figure 30), it is possible that microbial activities will continue unabated, even during the winter, to create

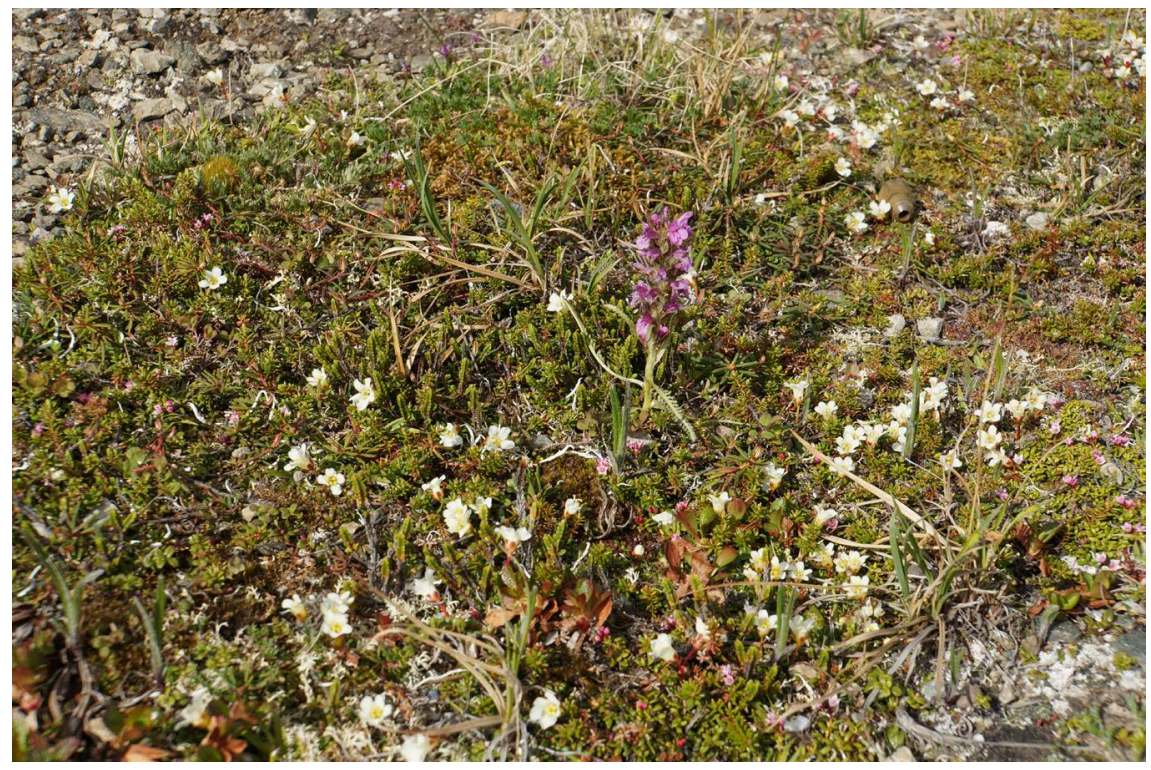

Figure 31. Tundra flowers on the Fairbanks to Circle trail. Photograph taken by Lois Wright Morton. 


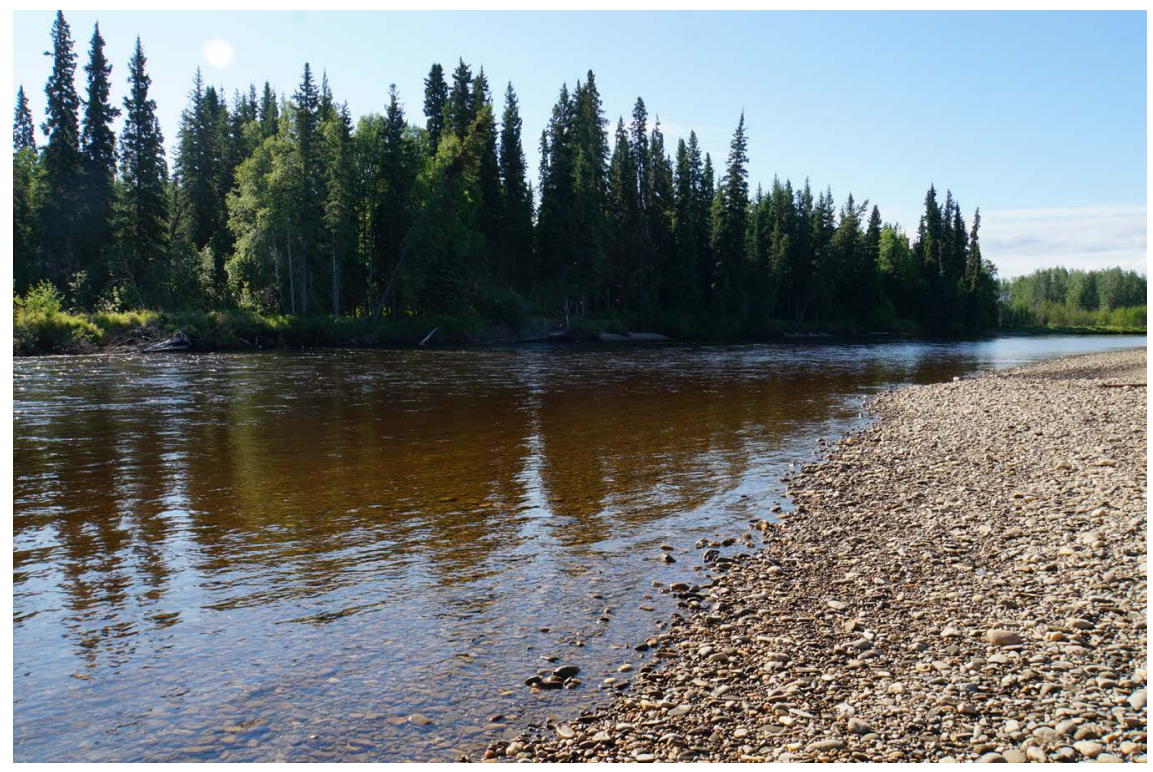

Figure 32. The soil organic carbon rich brown colored water of the Tanana River.

new methane from organic material.

\subsection{Natural Climate Change Effects}

Arctic permafrost has been diminishing for many centuries. At the last Glacial Maximum, continuous permafrost covered a much greater area than it does today. The consequence is thawing soil, which may be weaker, and release of methane, which contributes to an increased rate of global warming as part of a feedback loop.

The ground can consist of many substrate materials, including bedrock, sediment, organic matter, water or ice. Frozen ground is below the freezing point of water, whether or not water is present in the substrate. Ground ice is not always present, as may be the case with nonporous bedrock. By definition, permafrost is ground that remains frozen for two or more years. Since frozen soil, including permafrost, comprises a large percentage of substrate materials other than ice, it thaws rather than melts. One visible sign of permafrost degradation is the random displacement of trees from the vertical in permafrost areas [12] [13].

\subsection{Alyeska Pipeline}

The Trans-Alaska Pipeline System (TAPS) the trans-Alaska crude-oil pipeline (Figure 12), extends several hundred kilometers of feeder pipelines and 11 pump stations to the Valdez Marine Terminal. Commonly called the Alaska pipeline (Figure 33) or Alyeska pipeline, named after the company that built it, is $1280 \mathrm{~km}$ in length with a diameter of $1.22 \mathrm{~m}$. The pipeline goes from Prudhoe Bay to Valdez, Alaska. It was built after the 1973 oil crisis started in 1974 and completed in 1977. The oil crisis provoked the passage of legislation designed to remove legal challenges. Pipeline engineers had to overcome extreme cold and difficulty in isolated terrain. The pipeline project was one of the first large-scale 
projects to deal with permafrost related problems. Special construction techniques had to be developed to cope with the frozen ground. Production started in 1977 and has resulted in oil leakages from maintenance failures, sabotage and bullet holes. The pipeline now delivers over 2 million barrels of oil per day.

\subsection{Construction on Permafrost}

Building on permafrost is difficult because the heat from its construction along the pipeline or paved road can thaw the permafrost and destabilize the structure. Three common solutions include: using foundations on wood piles; building on a thick gravel pad (usually 1 - 2 meters); or using anhydrous ammonia heat pipes [14]. The Trans-Alaska Pipeline System (Figure 34) uses heat pipes built into

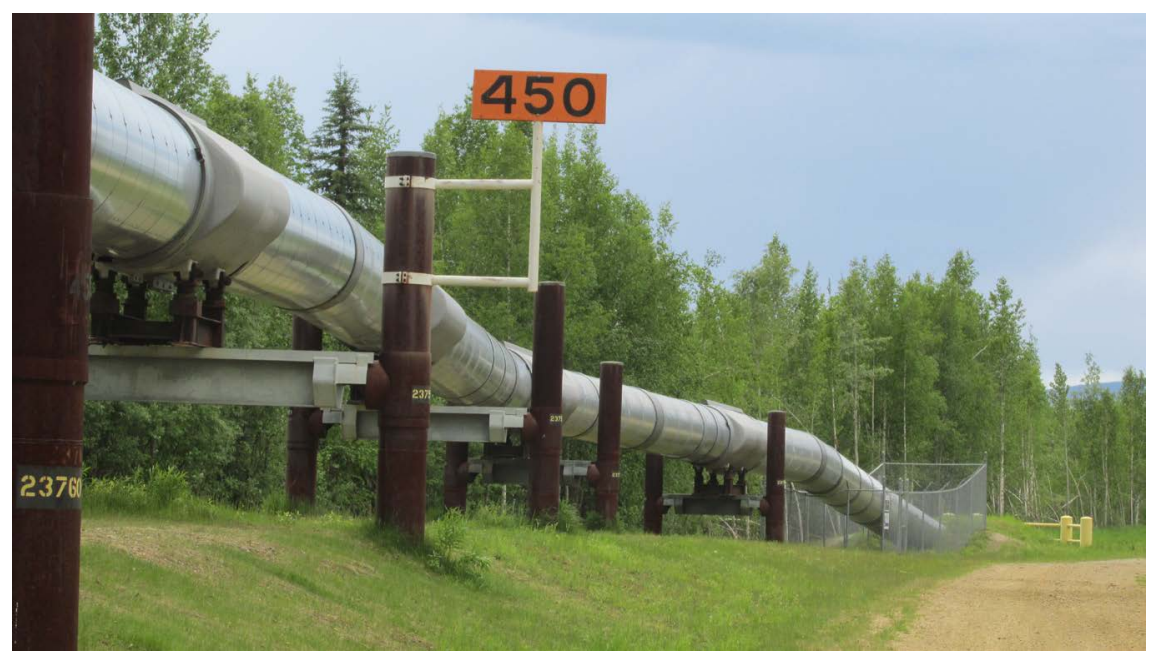

Figure 33. Alaska pipeline mile marker 450 located northeast of Fairbanks, Alaska. Photograph by Lois Wright Morton.

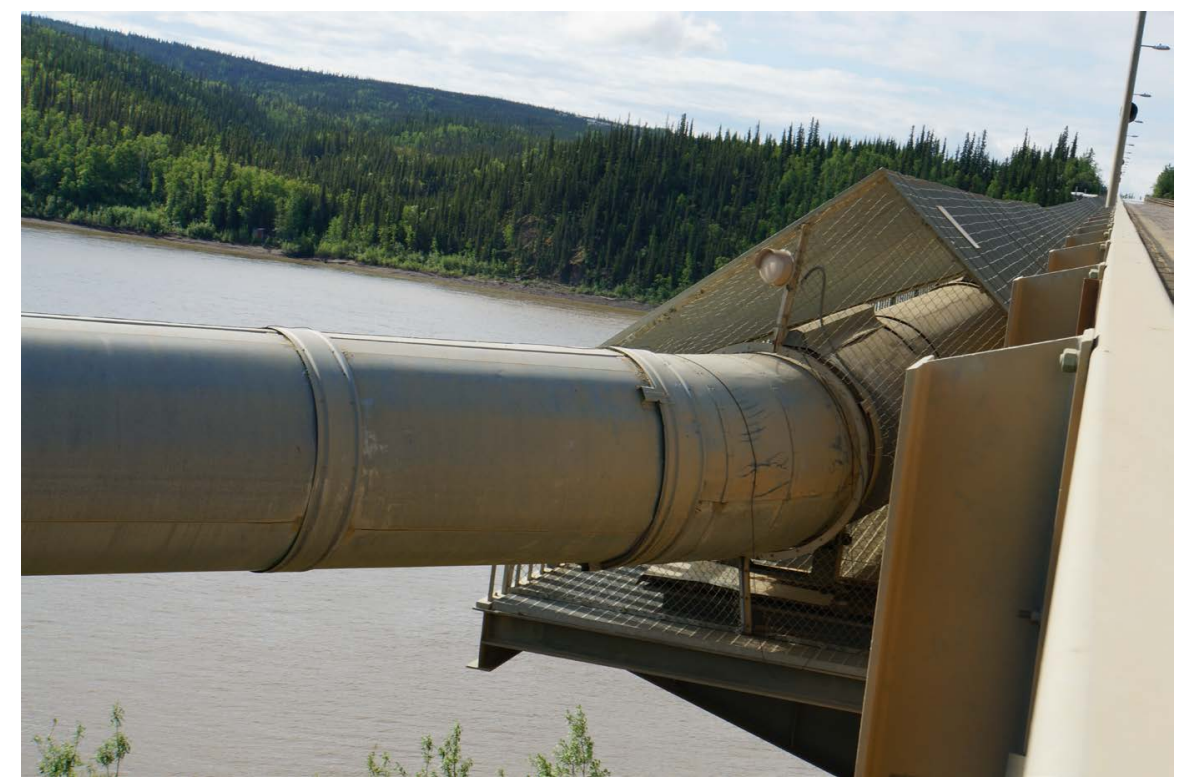

Figure 34. Alaska pipeline on the east side of the only Alaska Bridge over the $1280 \mathrm{~km}$ Yukon River. Photograph by Lois Wright Morton. 
vertical supports (Figure 35) to prevent the pipeline from sinking. Permafrost may necessitate special enclosures called "utilidors" for buried utilities.

The sinking of large buildings into the ground can be prevented by using pile foundations extending down to 15 meters or more. At this depth the temperature does not change with the seasons, remaining at about $-5^{\circ} \mathrm{C}$. Modern buildings in permafrost zones may be built on piles to avoid permafrost-thaw foundation failure from the heat of the building. Heat pipes in vertical supports maintain a frozen bulb around portions of the Trans-Alaska Pipeline that are at risk of thawing.

Roads in the permafrost (tundra and boreal forest) areas of Alaska are usually gavel even when the Alaskan Highway Department could have paved these roads. This does result in a lot of gravel damage to car and van windshields as vehicles pass each other especially on the Dalton Highway (Haul Road) to Prudhoe Bay and the North Shore of Alaska. These gravel roads transfer less heat to the permafrost layer which reduces possible melting of the permafrost layer. Subsequent road subsidence, results in fewer landslides or pavement shifts and cracking. They require fewer repairs and have fewer sinkhole collapses marked in pink to help drivers avoid them. When paved roads extend into the tundra or permafrost areas of Alaska, these roads quickly degrade (Figure 36) and are marked with pink circles showing the location of melted permafrost under the roadbed, resulting in constant series of dips (Figure 37), sending cars

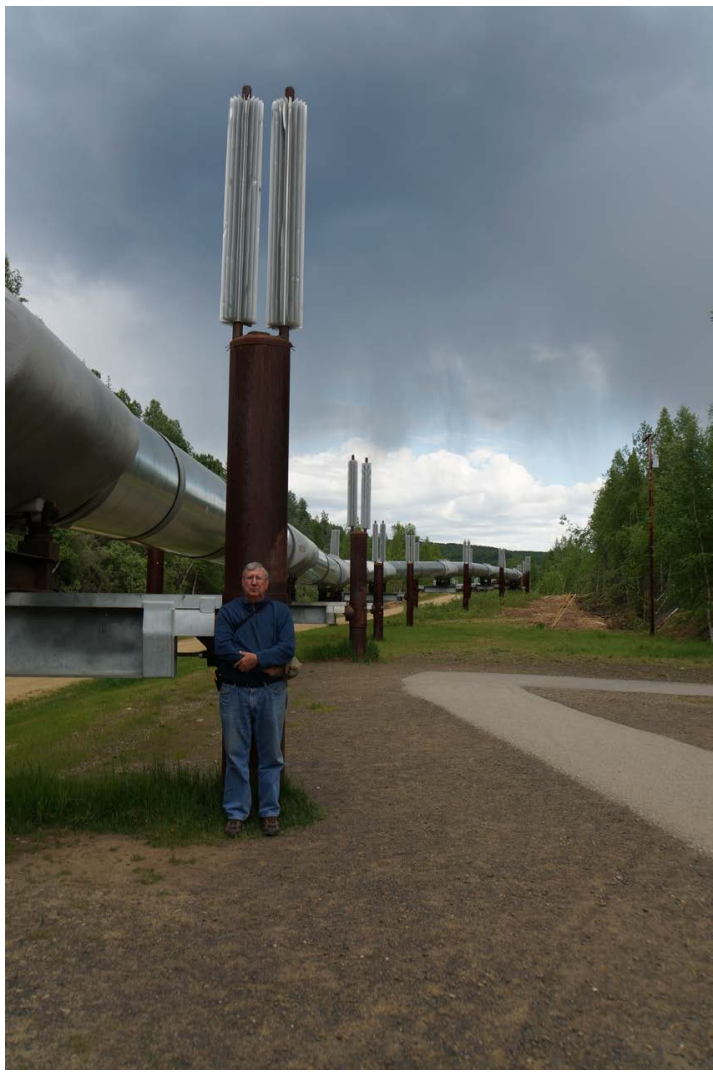

Figure 35. Heated pipes built into vertical supports for holding up the Alaska pipeline. 


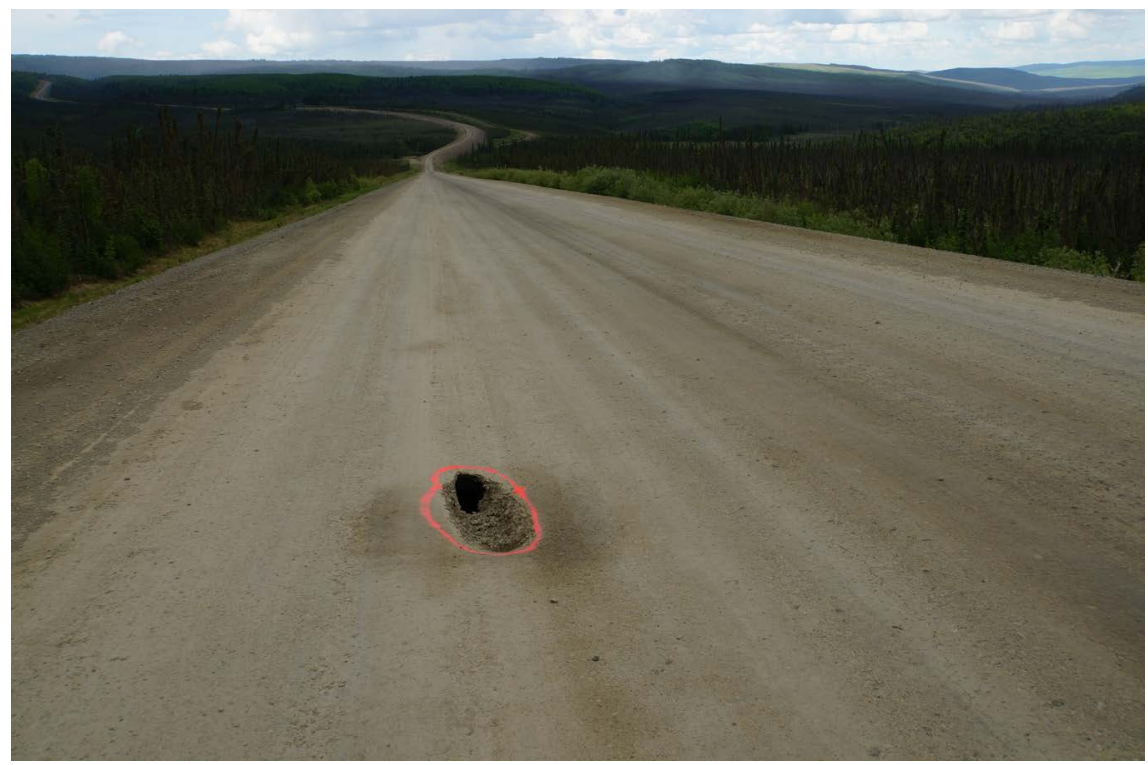

Figure 36. The Dalton Highway which has pink markings to warn drivers that there are sink holes where the permafrost has melted under the road bed. Photograph by Lois Wright Morton.

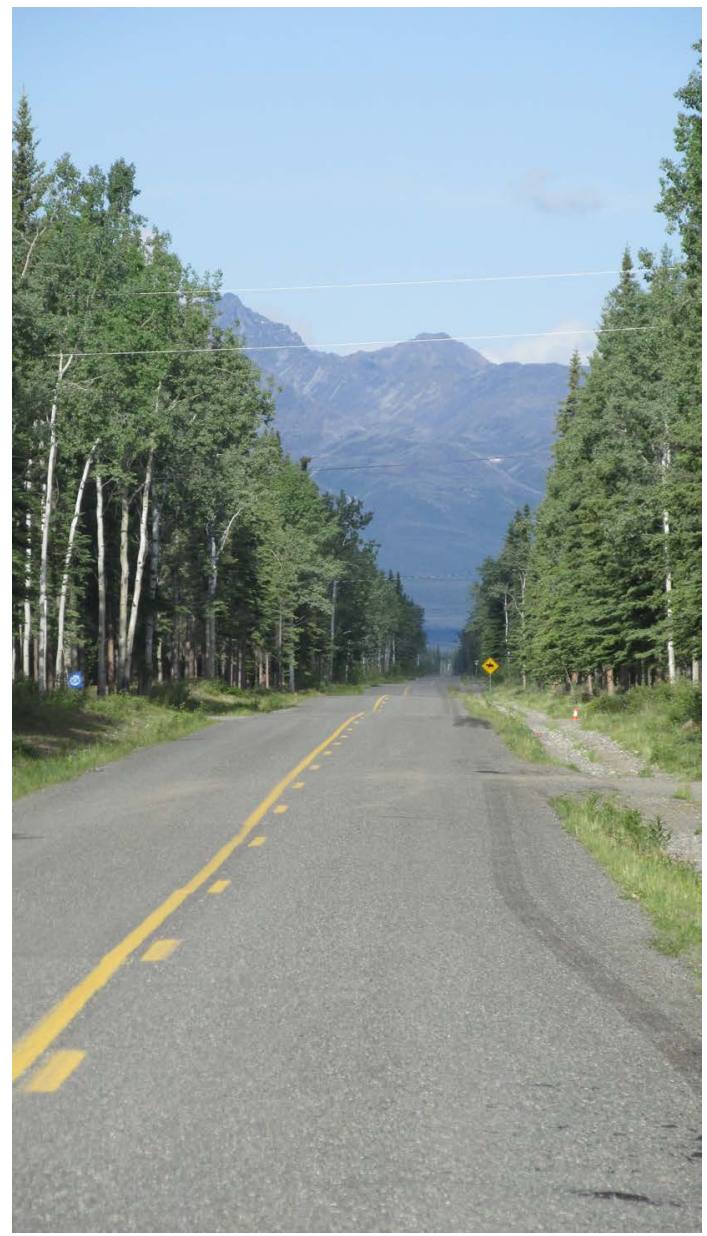

Figure 37. A local paved road with a series of dips caused by permafrost melting under the roadbed near Delta Junction, Alaska. 
and trucks flying into the air and then hitting bottom while driving at posted speeds. As one attempts to travel between Valdez and Prudhoe Bay along the Alaska Pipeline (Figure 38) by car or truck the only Alaskan bridge (Figure 39) across the $1280 \mathrm{~km}$ long Yukon River is on the Dalton Highway (Haul Road). This bridge cradles the pipeline on the east side of the bridge (Figure 34). The Dalton Highway (Figure 40) between Fairbanks to Coldfoot transports tourists by bus to the Arctic Circle, to observe the Northern Lights after August and before winter (October). Tourist buses use the Dalton Highway in June to witness the 24 hours of daylight and to see the sun touch the earth's horizon and go back up. Between June and September tourist buses leave Fairbanks and use the Dalton Highway to visit the oil and gas fields on the North Shore at Deadhorse. From the North Shore, tourists have the option of flying back to Fairbanks to avoid the return trip on the Haul Road.

\subsection{Effect on Slope Stability}

Over the past century, an increasing number of alpine rock slope failure events in mountain ranges around the world have been recorded. It is expected that the high number of structural failures is due to permafrost thawing (Figure 27), which is thought to be linked to climate change [1] [10] [15]. In mountain ranges, much of the structural stability can be attributed to glaciers (Figure 13) and permafrost. As climate warms, permafrost thaws, which results in a less stable mountain structure, and ultimately more slope failures [15]. Increasing temperatures allow deeper active layer depths (Figure 9), resulting in increased water infiltration. Ice within the soil melts, causing loss of soil strength, accelerated movement, and potential debris flows [16].

Instability of slopes in permafrost at elevated temperatures near freezing point in warming permafrost is related to effective stress and buildup of pore-water pressure in these soils. McSaveney [17] reported massive rock and ice falls (Figure 6), earthquakes, floods, and rapid rock-ice flow to long distances caused by "instability of slopes" in high mountain permafrost.

\subsection{Permafrost Holds the Tundra Landscape Together}

Frozen soil doesn't just lock up carbon-it physically holds the landscape together. In the summer, permafrost in the Arctic and Boreal regions is collapsing suddenly as pockets of ice melt within it. Instead of a few centimeters of soil thawing each year, several meters of soil can become destabilized within days or weeks. The land can sink and be inundated by swelling lakes and wetlands. When abrupt thawing of permafrost occurs, it can have significant impact on soil organic decomposition. In Alaska forested lands and hillsides can liquefy and slide and valleys can be covered with lakes. Streams and rivers that once ran clear are now filled with sediment (Figure 41). Roads buckle (Figure 37), houses become unstable. Access to traditional foods is changing, because it is becoming dangerous to travel across the land to hunt or trap. 


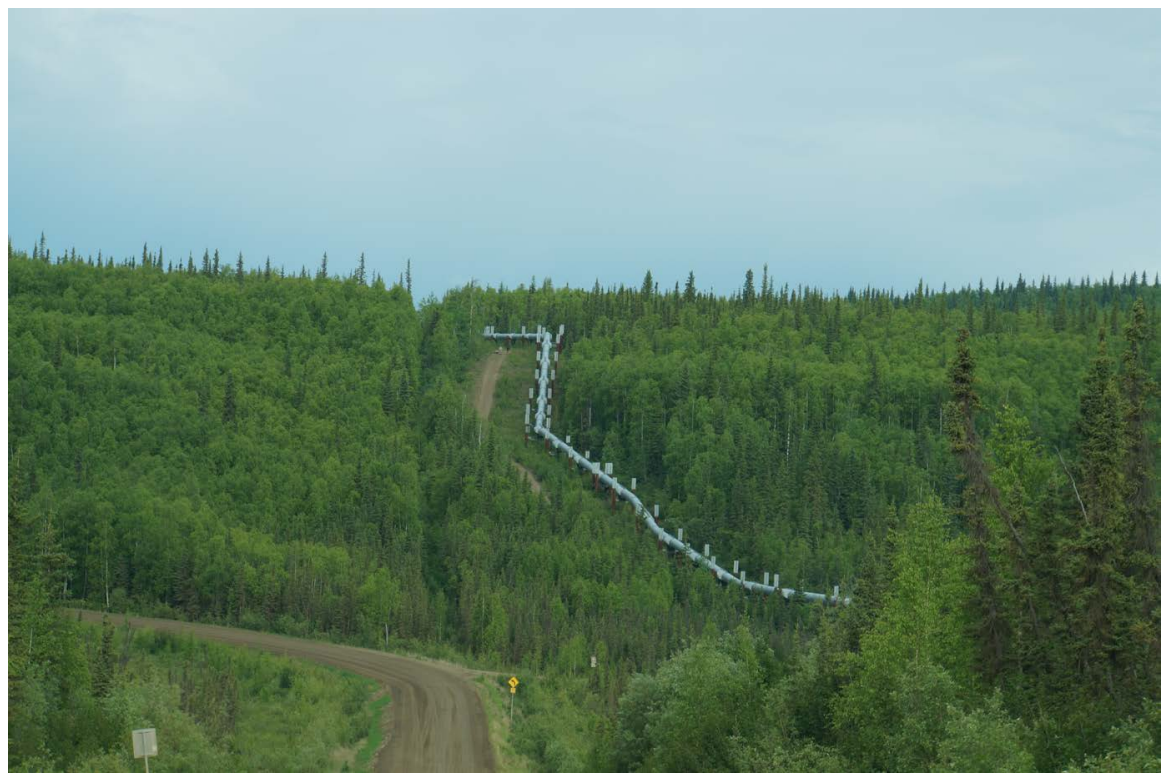

Figure 38. Alaska landscape with pipeline along the Haul road (Dalton Highway).

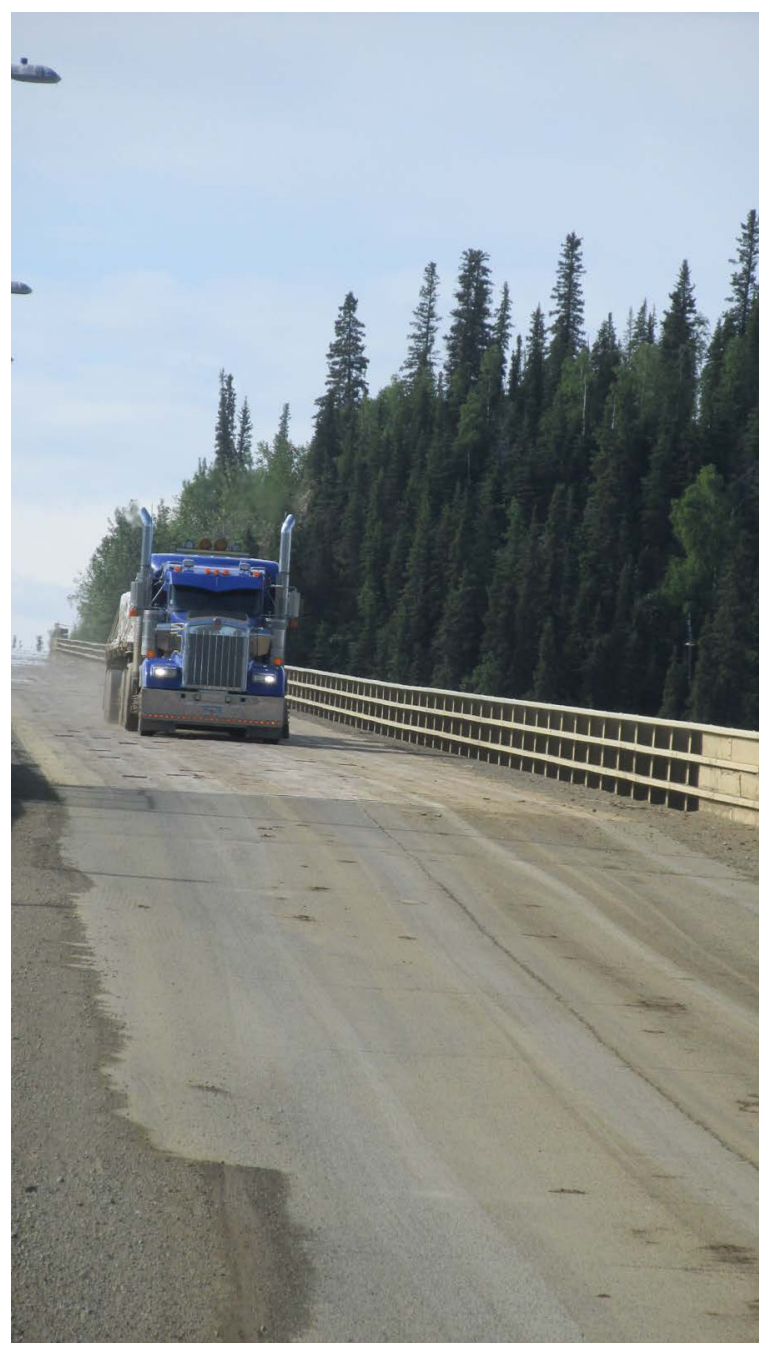

Figure 39. A truck on haul road and the only Alaskan bridge over Yukon River. 


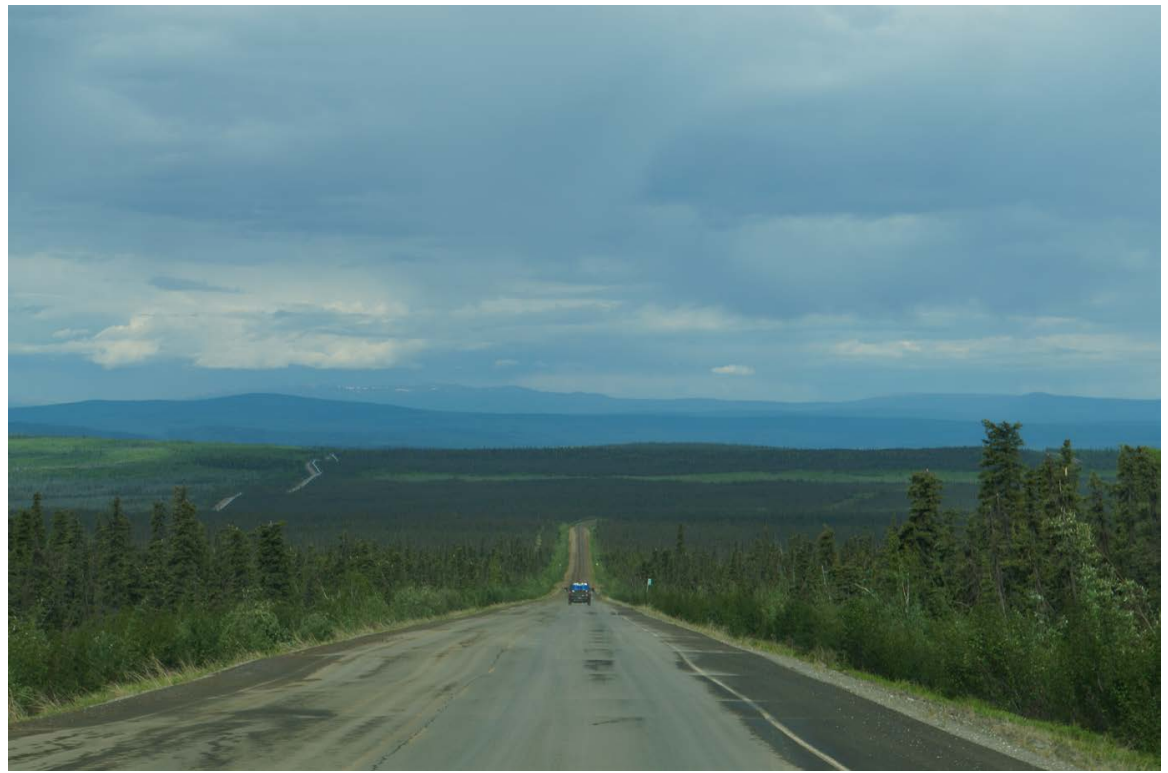

Figure 40. The Dalton Highway (Haul Road) which is a gravel road.

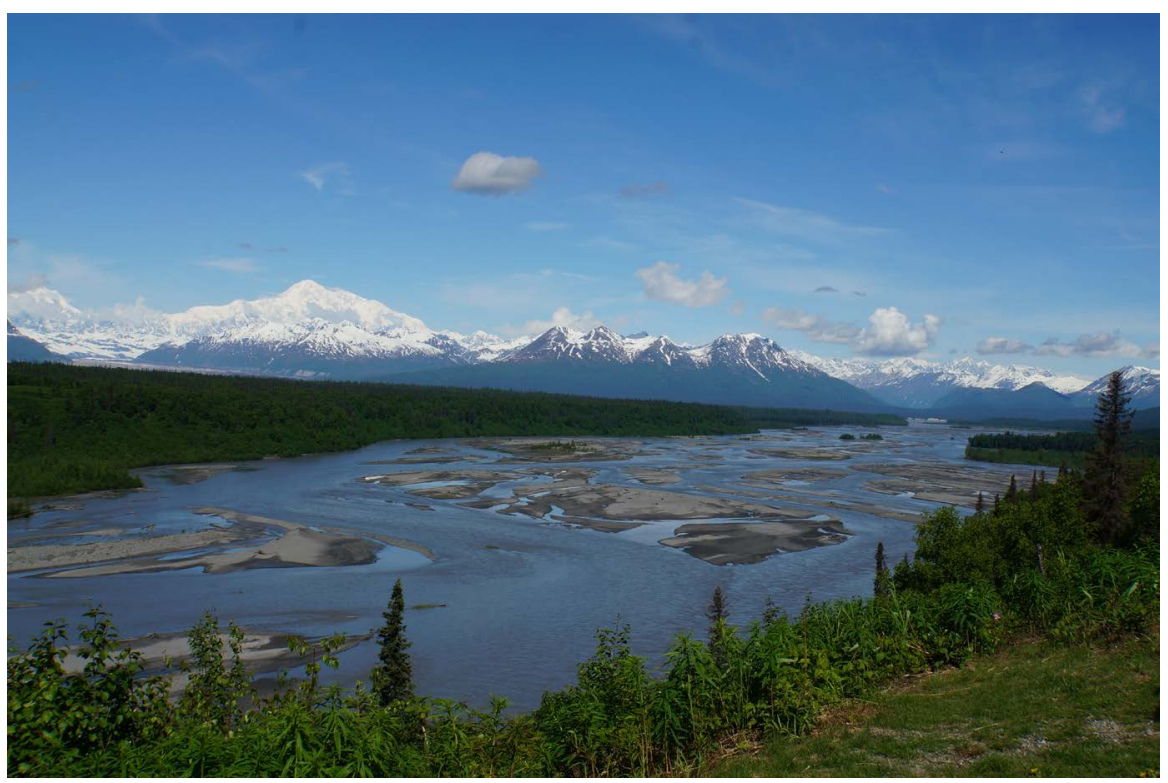

Figure 41. Fine earth deposits on Susitna River in Alaska. Denali in the background. Photograph by Lois Wright Morton.

\subsection{Ecological Consequences}

In the northern circumpolar region, permafrost (Figure 27) contains 1760 billion $\mathrm{mt}$ of organic material equaling almost half of all organic material in all soils [7]. This pool was built up over thousands of years and is only slowly degraded under the cold conditions in the Arctic. The amount of carbon sequestered in permafrost is four times the carbon that has been released to the atmosphere due to presumed human activities in modern time [10]. One manifestation of this is yedoma, which is an organic-rich (about $2 \%$ carbon by mass) Pleistocene-age loess permafrost with an ice content of $50 \%-90 \%$ by volume [18]. 
Formation of permafrost has significant consequences for ecological systems, primarily due to constraints imposed upon rooting zones, but also due to limitations on den and burrow geometries for fauna requiring subsurface homes. Secondary effects impact species dependent on plants and animals whose habitat is constrained by the permafrost. The dominance of black spruce in extensive permafrost areas occurs since this species can tolerate rooting pattern constrained to the near surface [19].

The Arctic region is one of the many natural sources of greenhouse gas methane [20]. Global warming accelerates its release, due to both release of methane, from existing stores and from methanogenesis in rotting biomass [18]. Large quantities of methane are stored in the Arctic in natural gas deposits, permafrost, and as submarine clathrates (host-guest complexes). Permafrost and clathrates degrade on warming, thus large releases of methane from these sources may arise as a result of global warming [21]. Other sources of methane include submarine talks (year around unfrozen soil layers), river transport (Figure 42 and Figure 30), ice complex retreat, submarine permafrost and decaying gas hydrate deposits [22].

\subsection{Predicted Rate of Change in the Arctic}

According to Intergovernmental Panel on Climate Change (IPCC) Fifth Assessment Report [23], there is high confidence that permafrost temperatures have increased in most regions since the early 1980s. Observed warming was up to $3^{\circ} \mathrm{C}$ in parts of Northern Alaska (early 1980s to mid-2000s) [24]. In the Yukon, the zone of continuous permafrost might have moved $100 \mathrm{~km}$ northward since 1899, but accurate records only go back 30 years. It is thought that permafrost thawing could exacerbate global warming by releasing methane and other hydrocarbons, which are powerful greenhouse gases [25] [26]. It also could

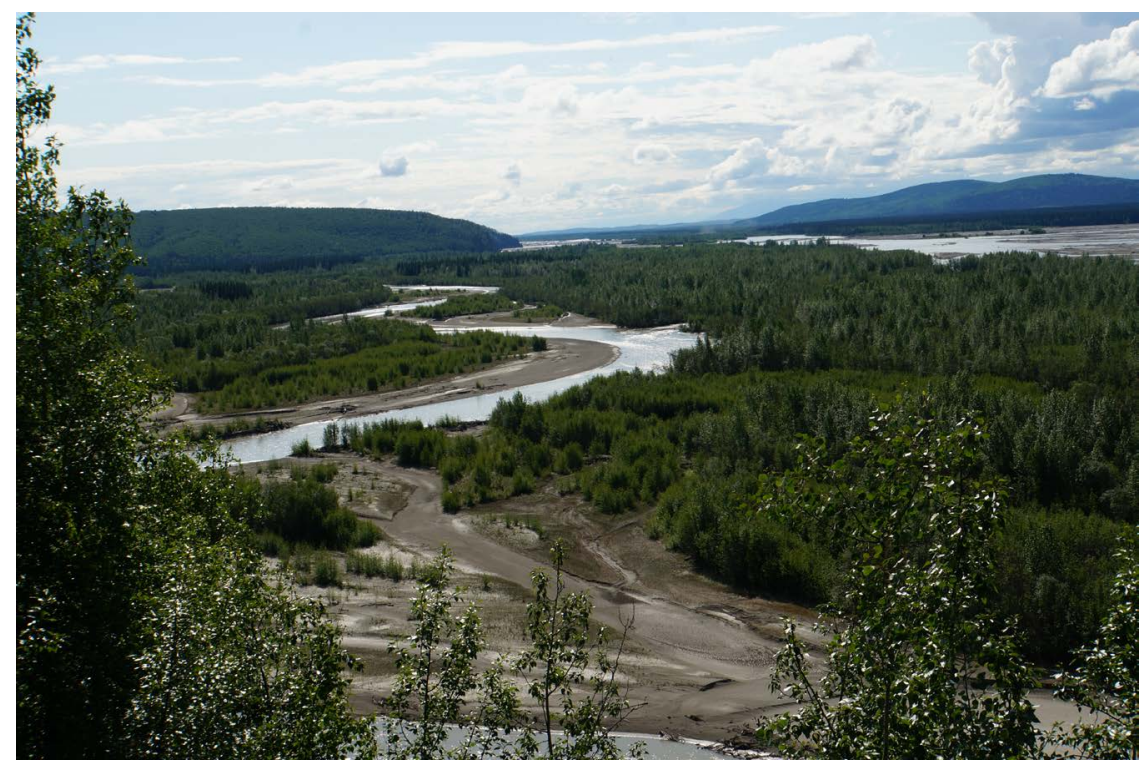

Figure 42. Fine sediment deposited in the braided Tanana River. 
increase soil erosion and landslides (Figure 43 and Figure 44) because permafrost lends stability to barren Arctic slopes. Arctic temperatures are expected to increase at roughly twice the global rate [24].

\subsection{The Effect of Natural Climate Change on Permafrost}

The upper layer of permafrost, or the active layer, sometimes thaws in the summer. Climate change is expected to significantly affect above and below-ground climate [1] [10] [15]. Recent studies have shown that there has been a decrease in freezing during the cold season in North America's permafrost regions. Coastal areas and eastern Canada have started to see significant increases in

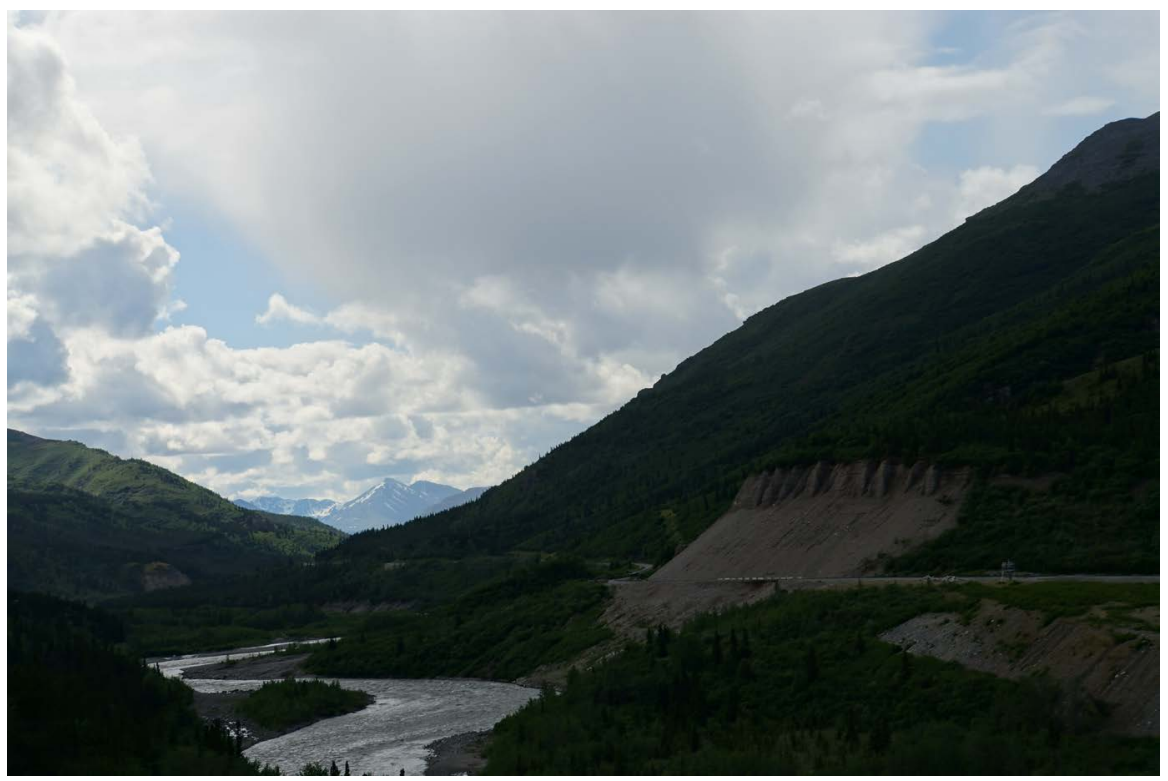

Figure 43. Landslides along highway between Fairbanks and Anchorage.

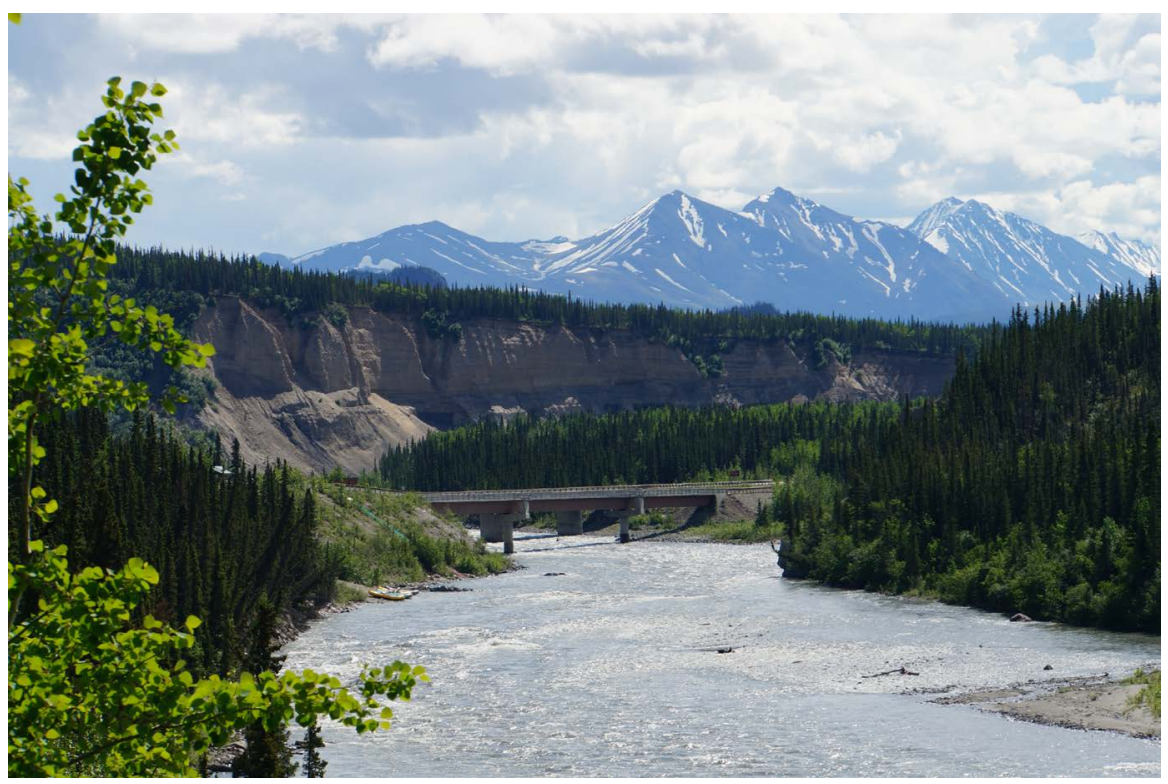

Figure 44. Tanana River is undercutting the river bank cause a landslide. 
warm season thawing of permafrost. This means there has been a decrease in freeze depths and in the amount of permafrost, and an increase in the area of the active layer.

Melting permafrost results in the upper soil layers becoming drier and well aerated. Even if permafrost remains as temperatures increase, the shallow surface soil layers become deeper creating a thicker unsaturated zone. Soil microbes increasingly oxidize the soil organic carbon stock. Increase plant respiration releases carbon, in the form of carbon dioxide, into the atmosphere or as dissolved carbon into the stream [27]. Changes in dissolved organic carbon (DOC) can affect stream aquatic community's at all tropic levels that rely on DOC as a food source. Melting of permafrost may increase recharge of aquifers and increase base flow into streams. By increasing summer recharge, melting of permafrost will decrease summer peak flows. Wetlands occupy about 30\% of the Yukon River basin primarily the Yukon Flats and the Yukon Delta. Wetlands are the lands transitionally between terrestrial and deep water habitats [27] where the water table is at or near the soil surface or covered by shallow water [28]. Melting of permafrost can, in turn, affect waterfowl (Figure 45) in the Yukon Flats and Yukon Delta areas.

Another natural factor that can impact permafrost is fire. Wildfires [28] disturb thousands of hectares of land in the Yukon River Basin each year. The wild fires expose soil to erosion, transport and deposition. Foot [28] has estimated that natural fire cycle ranges from 70 to 130 years. Fire changes the surface conditions and results in soil warming and increases biological activity zone within a soil. The soil may become well drained and no longer have a perched water table. The hydrology changes the areas that were once wetlands and they become well drained.

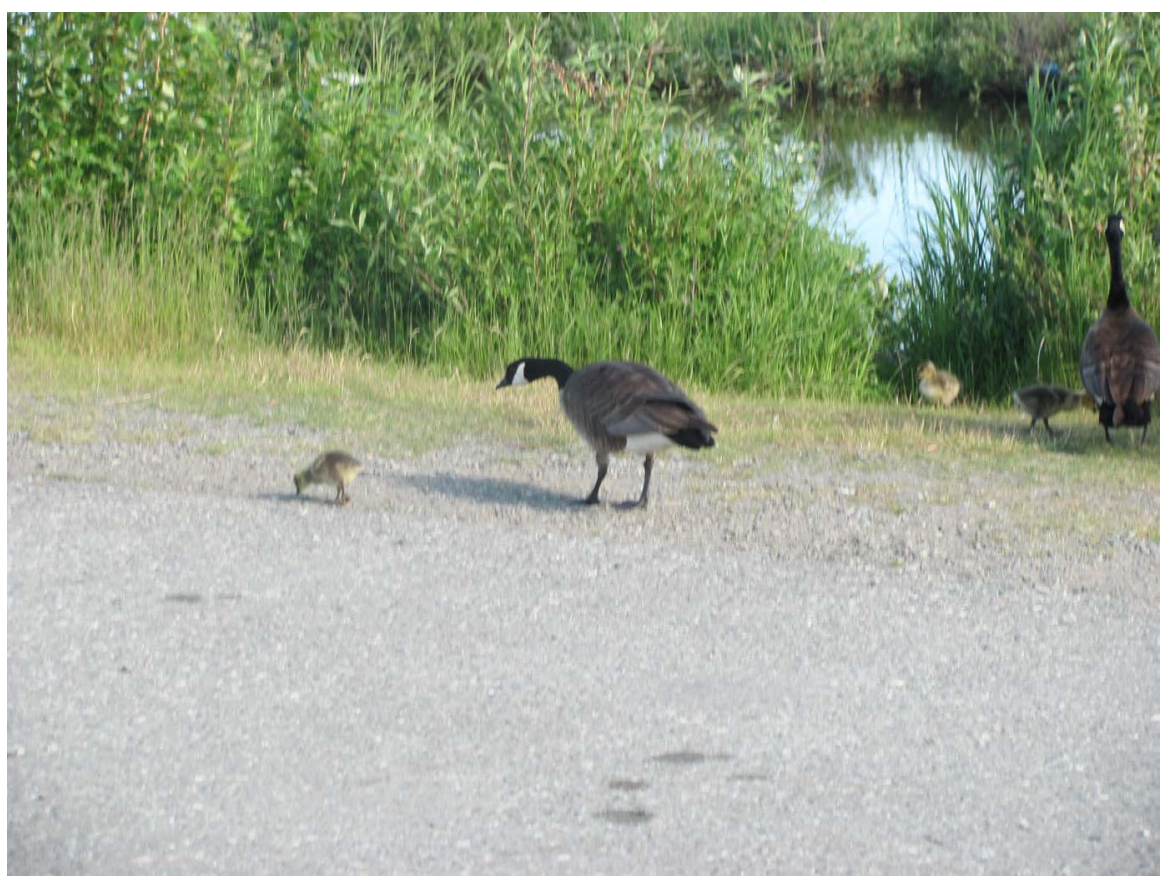

Figure 45. Geese crossing the road near a wetland. Photograph by Lois Wright Morton. 


\subsection{Anthropogenic Effects on Water Quality}

Discussions of the water quality of the Yukon River Basin are based on limited data and indicate that water chemistry differences throughout the basin are due more to natural factors rather than to human-induced factors. However, the basin has been affected by limited human activities within the basin and from outside the basin. The difficulty arises in determining to what degree humans have affected the water quality, because a suitable water-quality data base does not exist at the present time. The Yukon River Basin is not subject to the intensive agricultural cultivation or application of organic pollutants found in some rivers of the lower 48 states. It is more vulnerable to global atmospheric transport of pollutants that is well recognized.

In the northern hemisphere, transport occurs primarily in the winter months when temperature and pressure gradients are the greatest. Pollutants from mid-latitudes are transported northward, where greater precipitation and colder temperatures cause deposition from a "warm-cold distillation" effect [29]. Chlorinated pesticides, such as $\mathrm{HCH}, \mathrm{HCS}, \mathrm{DDT}$, toxaphene, and chordates, have been observed in the Arctic and are believed to have been transported in the atmosphere. Many of the compounds are lipophilic, concentrating on the fat and fatty tissues of fish and game animals. In 1991, elevated levels of toxaphene, DDT, and PCB's were found in burbot (Lota lota) liver, and lake trout (Salvelinus namaycush) and whitefish (Coregonus clupeaformis) muscle in Lake Laberge near the headwaters of the Yukon River [30]. The concentrations in Lake Laberge whitefish were 3 to 42 times higher than those in whitefish from other lakes in the region [30]. Atmospheric transport was determined to be the source of the pollutants in predatory fish [31].

Mining activity (Figure 8) has, and continues to be, an important economic industry in the Yukon River Basin. Probably the biggest concern of mining is the possible harm to fish-spawning areas. Although today's mining practices are highly regulated to prevent damage to fish habitat, many old abandoned mine areas remain to be reclaimed. The Coal Creek watershed, located in $\mathrm{Yu}$ kon-Charley Rivers National Preserve, was mined extensively in the early 1900s and mining practices used at the time had a severe impact on the watershed. The site was declared a Superfund site by the U.S. Environmental Protection Agency and cleanup was completed in 1998. During the Cold War, the military had a strong presence in Alaska. Military bases located near Fairbanks (Figure 46) and Delta Junction, early warning radar sites were located at some villages along the Yukon River. At the U.S. Air Force Base at Galena during a flood, 250,000 drums containing potentially toxic materials are currently spread out across the tundra. The effect on water quality has yet to be determined.

\subsection{Sediment Sources}

Sediment in streams and rivers in the Yukon River Basin is primarily the result of natural erosion, transport and deposition (Figure 47). The soil erosion and 


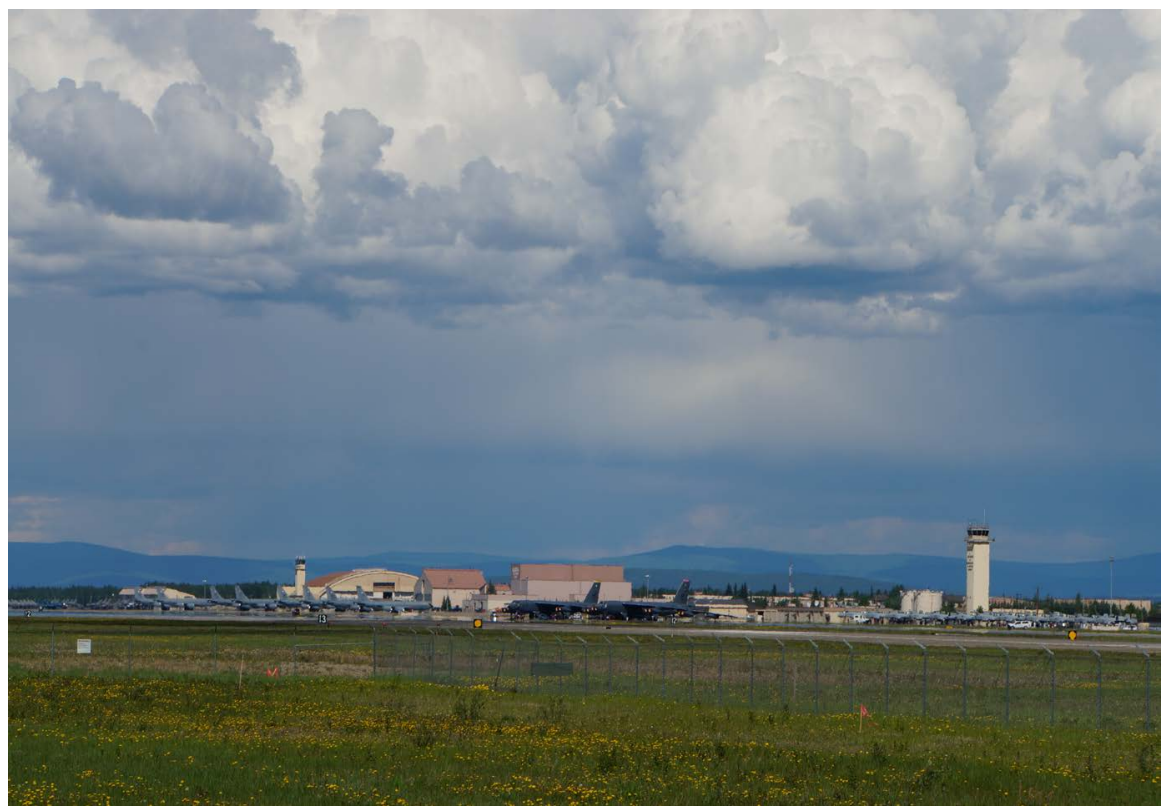

Figure 46. The US Air Force base east of Fairbanks on the Alaska Highway. Photograph by Lois Wright Morton.

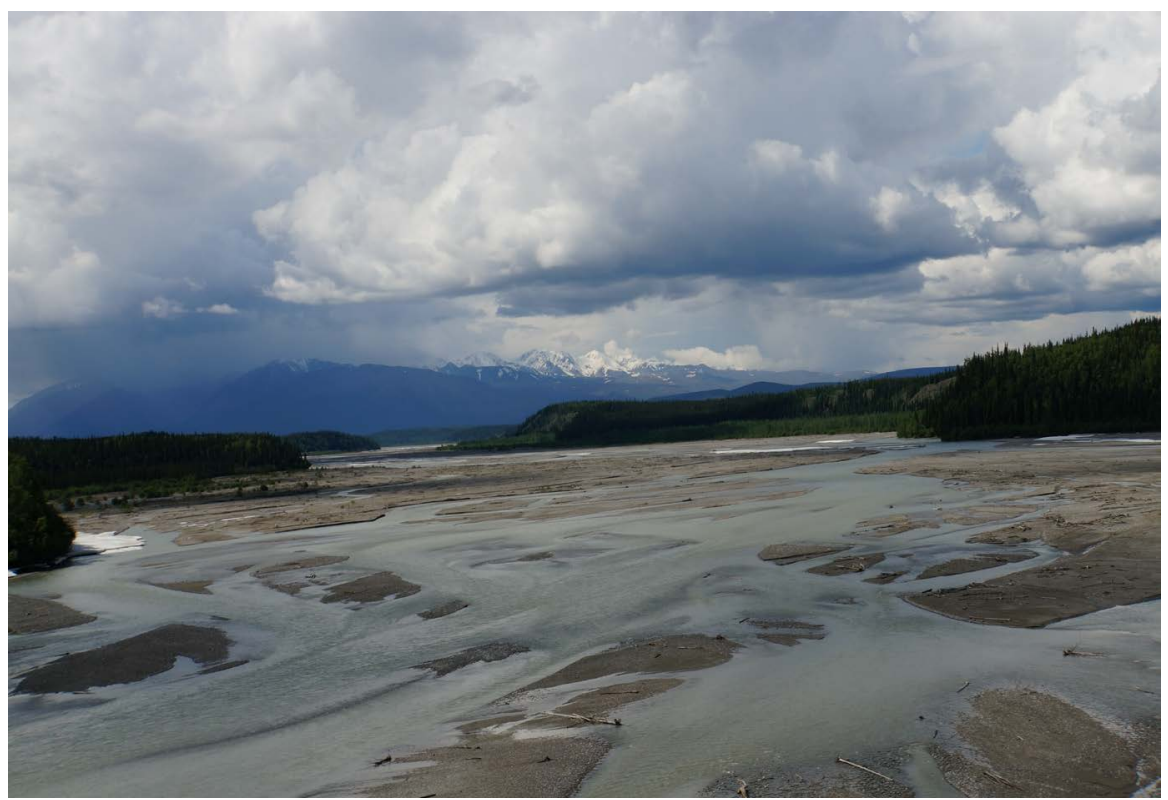

Figure 47. Fine sediment in a river with the mountains in the background.

sediment process can be accelerated by fire and as a result of land cover loss and soil disturbance by mining and other human activities.

Non-glacier-fed tributaries of the Yukon River have beds composed of sand, gravel and cobbles. The coarser material is found in upper headwater streams and the finer material is in the lower stream areas. Banks consist of poorly sorted material in the higher stream valleys. Material is gradually sorted and rounded when transported, consisting of smaller gravel and cobbles with sand and gravel on the Yukon's river bars. Glacier-fed rivers in Yukon River have vast quantities 
of unconsolidated material downstream from the glaciers. These rivers have wide floodplains cut with braided channels. Boulders, cobbles, gravel, sand and large quantities of the silt make up the stream banks and bed and stream bank erosion can provide a source of sediment.

In areas of the Yukon River Basin with discontinuous permafrost, the riverbanks may be permanently frozen and overlain by seasonally frozen layers of organic material and plants. This condition creates an additional source of sediments in the summer when permafrost melts while flowing water transports sediment into the streams and rivers. Most of the measured suspended sediment concentrations for the mainstream of the Yukon River were less than $1000 \mathrm{mg} / \mathrm{l}$. The two major glacier-fed rivers, the White and the Tanana had the highest concentrations.

\section{Summary and Conclusions}

The soil erosion, transport, deposition and storage of sediments determine the habitat distribution and water quality within the Yukon River and tributary floodplains and river channels. The ecological functioning, with food and nutrient delivery, migratory cues, breeding, habitats and floodplain and riparian ecological cycles are all dependent on the soil erosion and sediment transport at specific times of the year. The Yukon River transports about 58.8 million mt of suspended sediment per year to the Bering Sea. Each year, about 19.6 million mt of sediment are deposited on floodplains and braided sections of the river. Organic carbon, contaminants and nutrients are either absorbed on the sediment or are suspended in solution. The amount of the organic carbon sequestered sediments is huge. Total organic carbon concentrations are highest in the regions with organic soils.

Sedimentation within the Yukon River basin is rather unique. Most North American rivers have agriculture as the dominant land use and acceleration erosion from agricultural use as the primary sediment source. This is not the situation in the Yukon River Basin. Most of the sediment comes from natural soil erosion sources in the surrounding wilderness. Rainfall and runoff, glaciers melting, permafrost melting or after fires all contribute to soil erosion and sedimentation. Soil disturbances by human activities do contribute to the Yukon River and tributary soil erosion and sediment loads. The rivers transport vast quantities of soil organic carbon and sediment which are sequestered or stored in the floodplains, in the Yukon Delta or deposited in the Bering Sea.

\section{Acknowledgements}

Published with funding support from USDA, NIFA, Water Division and the Department of Natural Resources and Environmental Sciences. Published with the approval of the Director of the Illinois Office of Research, College of Agricultural, Consumer, and Environmental Science, University of Illinois, Urbana, Illinois. 


\section{Conflicts of Interest}

The authors declare no conflicts of interest regarding the publication of this paper.

\section{References}

[1] Brabets, T.P., Wang, B. and Meade, R.H. (2007) US Geological Survey. Water Resources Investigation Report 99-4204.

[2] Wikipedia (2020) Yukon River. The Free Encyclopedia. Wikimedia Foundation, San Francisco.

[3] Alaska Department of Labor 9199) Research \& Analysis. Demographic Unit, Population Estimates. http://www/labor/alaska/gov/trends/trendspdf/dec99.pdf

[4] Environment Canada (2002) Yukon Environment. Yukon Department of Environment. http://wwu/environmentyukon.gov.yk.ca/soe/soe.shtml

[5] USDA, NRCS Staff (2007) Soils Taxonomy-A Basic System of Soil Classification for Making and Interpreting Soil Surveys. Soil Conservation Service. USDA Handbook 436, $754 \mathrm{p}$.

[6] Ferrians, O.T. (1965) Permafrost Map of Alaska, US Geological Survey. Miscellaneous Geologic Investigations Map I-445, Scale 1:2,500,000. G.

[7] Tarnocai, et al. (2009) Soil Organic Carbon Pools in the Northern Circumpolar Permafrost Region. Global Biogeochemical Cycles, 23, GB2023. https://doi.org/10.1029/2008GB003327

[8] Heginbottom, J.A., Brown, J., Humlum, O. and Svensson, H. (2009) State of the Earth's Cryosphere at the Beginning of the 21st Century: Glaciers, Global Snow Cover, Floating Ice, and Permafrost and Periglacial Environments. A435.

[9] Michaelson, G.J., Ping, C.L. and Clark, M. (2013) Soil Pedon Carbon and Nitrogen Data for Alaska: An Analysis and Update. Open Journal of Soil Science, 13, 132-142. https://doi.org/10.4236/ojss.2013.32015

[10] Schuur, E.A.G., et al. (2011) High Risk of Permafrost Thaw. Nature, 480, 32-33. https://doi.org/10.1038/480032a

[11] McGuire, A.D., Anderson, L.G., Christensen, T.R., Dallimore, S., Guo, L., Hayes, D.J., Heimann, M., Lorenson, T.D., Macdonald, R.W. and Roulet, N. (2009) Sensitivity of the Carbon Cycle in the Arctic to Climate Change. Ecological Monographs, 79, 523-555. https://doi.org/10.1890/08-2025.1

[12] Stevens, W.K. (1998) Dead Trees and Shriveling Glaciers as Alaska Melts. The New York Times.

[13] de Villiers, M. (2001) Water: The Fate of Our Most Precious Resource. Mariner Books, Boston.

[14] Clarke, E.S. (2007) Permafrost Foundations-State of the Practice. Monograph Series. American Society of Civil Engineers, Reston. https://doi.org/10.1061/9780784409473

[15] Huggel, C., Allen, S. and Deline, P. (2012) Ice Thawing, Mountains Falling; Are Alpine Rock Slope Failures Increasing? Geology Today, 28, 98-104. https://doi.org/10.1111/j.1365-2451.2012.00836.x

[16] Darrow, M., Gyswyt, N., Simpson, J., Daanen, R., Hubbard, T., et al. (2016) Frozen Debris Lobe Morphology and Movement: An Overview of Eight Dynamic Features, Southern Brooks Range, Alaska. The Cryosphere, 10, 977-993.

https://doi.org/10.5194/tc-10-977-2016 
[17] McSaveney, M.J. (2002). Recent Rockfalls and Rock Avalanches in Mount Cook National Park, New Zealand. In: Catastrophic Landslides, Effects, Occurrence and Mechanisms, Geological Society of America, Reviews in Engineering Geology, Boulder, Volume XV, 35-70. https://doi.org/10.1130/REG15-p35

[18] Walter, K.M., Zimov, S.A., Chanton, J.P., Verbyla, D. and Chapin, F.S. (2006) Methane Bubbling from Siberian Thaw Lakes as a Positive Feedback to Climate Warming. Nature, 443, 71-75. https://doi.org/10.1038/nature05040

[19] Hogan, C.M. (2008) Black Spruce: Picea mariana. GlobalTwitcher.com.

[20] Bloom, A.A., Palmer, P.I., Fraser, A., Reay, D.S. and Frankenberg, C. (2010) Large-Scale Controls of Methanogenesis Inferred from Methane and Gravity Spaceborne Data. Science, 327, 322-325. https://doi.org/10.1126/science.1175176

[21] Pfeiffer, E.M., Grigoriev, M.N., Liebner, S., Beer, C. and Knoblauch, C. (2018) Methane Production as Key to the Greenhouse Gas Budget of Thawing Permafrost. Nature Climate Change, 8, 309-312. https://doi.org/10.1038/s41558-018-0095-z

[22] Shakhova, N. and Semiletov, I. (2007) Methane Release and Coastal Environment in the East Siberian Arctic Shelf. Journal of Marine Systems, 66, 227-243.

https://doi.org/10.1016/j.jmarsys.2006.06.006

[23] Intergovernmental Panel on Climate Change (IPCC) (2015) Fifth Assessment Report Climate Change 2013-Summary for Policymakers-Template Lab.

[24] Intergovernmental Panel on Climate Change (IPCC) (2007) Summary for Policy Makers. In: Solomon, et al., Eds., Climate Change 2007: The Physical Basis. Working Group I Contribution to the Fourth Assessment Report of the Intergovernmental Panel on Climate Change, Cambridge University Press, Cambridge.

[25] Sample, I. (2005) Warming Hits “Tipping Point”. The Guardian.

[26] Schuur, E.A.G., Vogel, J.G., Crummer, K.G., Lee, H., Sickman, J.O. and Osterkamp, T.E. (2009) The Effect of Permafrost Thaw on Old Carbon Release and Net Carbon Exchange from Tundra. Nature, 459, 556-559. https://doi.org/10.1038/nature08031

[27] Cowardin, L.M., Carter, V., Golet, F.C. and LaRoe, E.T. (1979) Classification of the Wetlands and Deepwater Habitats of the United States. US Fish and Wildlife Service Report FWS/OBS 79/31, 131 p.

[28] Foot, M.T. (1976) Classification, Description and Dynamics Interior Alaska-Fire Effects Study, Fairbanks, Alaska. USDA Forest Service, Institute of Northern Forestry Report.

[29] Majewski, M.S. and Capel, P.D. (1996) Pesticides in the Atmosphere-Distribution, Trends and Governing Factors. Ann Arbor Press, Chelsea, 214 p.

[30] Muir, D. and Lockhart, W.L. (1992) Food Chain Accumulation and Biochemical Effects of Organochlorine Contaminants in Fish from Lake Laberge and the Other Yukon Lakes. In: Murray, J.L. and Shearer, R.G., Eds., Synopsis of Research Conducted under the 1991/1992 Northern Contaminants Program, Minister of Indian Affairs and Northern Development, Ottawa, Environmental Studies No. 68, 173-177.

[31] Kidd, K.A., Schindler, D.W., Muir, D.C., Lockhart, W.L. and Hesslein, H.R.H. (1995) High Concentrations of Toxaphene in Fishes from a Subarctic Lake. Science, 269, 240-241. https://doi.org/10.1126/science.269.5221.240 